\title{
Targeting and Attacking America
}

\author{
Victor H. Asal \\ Professor \\ Department of Political Science \\ E-mail: vasal@albany.edu•Tel: (518) 591-8729•Milne 217 \\ R. Karl Rethemeyer \\ Dean \& Professor \\ Rockefeller College of Public Affairs \& Policy \\ E-mail: kretheme@albany.edu • Tel: (518) 442-5283• Milne 102B
}

Rockefeller College of Public Affairs \& Policy

University at Albany - State University of New York

1400 Washington Avenue

Albany, NY 12222 USA 


\title{
Targeting and Attacking America
}

\begin{abstract}
Hating America - and targeting or killing Americans - at times seems like a mandatory activity for terrorists, yet only a small minority of known terrorist organizations target or attack American interests. Under what circumstances do terrorist organizations choose to target American citizens and interests? When do they actually commit such attacks? To answer these questions, we leverage data from the Memorial Institute for the Prevention of Terrorism's database on terrorist organizations and attacks. Our model focuses on two broad dimensions of organizations - their motivations and capabilities. Our statistical analysis finds that the factors that drive an organization to target US interests are not completely co-terminus with those factors that help to explain the pattern of actual attacks. The propensity to target and to attack US interests are both related to alliance connections and basing of US troops in authoritarian countries that host a given terrorist organization. Targeting is negatively related to the cultural and economic integration of an organization's "host" country with the United States and state sponsorship and positively related to adherence to an Islamic ideology. Attacks on US interests are positively related to cultural ic embedding, negatively related to economic embedding, and more likely when the organization is more experienced with terrorism.
\end{abstract}




\section{Introduction}

Hating America - and killing Americans - at times seems like a mandatory activity for terrorist organizations. One researcher of terrorism went so far as to argue that "it is worth stating at the beginning that despite various goals and motivations of modern terrorists, antiAmericanism is probably the most universal and widespread of attitudes. Terrorists of the extreme Right and Left, religious fundamentalists, members of radical ecological movements, and anti-globalists treat the United States as the main obstacle to realizing their ideals and dreams (Stankiewicz, 2005, 784)." When one looks at the record of domestic and international terrorists, though, only a small minority of identified organizations actually select American targets for international or transnational terrorism, and a somewhat larger number have actually attacked "US interests" (MIPT, 2006), here defined as any attack on a US citizen, US-owned businesses or nonprofits, or US affiliated businesses or nonprofit organizations. ${ }^{1}$ Nonetheless terrorist organizations that (a) target the United States (which we define as having expressed an intention to attack US interests domestically or internationally) and/or (b) have actually attacked US interests have had an enormous effect, resulting in two wars in the last decade, the first major reorganization of the United States government since World War II, and an enormous shift in the allocation of federal and state resources (Betts, 2002, 27).

Despite this enormous redeployment of public resources, as far as we know no one has actually studied the factors that make a terrorist organization - here defined as a social entity that (a) seeks to influence policy and politics by using violence to instill "fear and alarm" (MIPT, 2006) against civilians and (b) possesses a boundary (i.e., a process that separates members from non-members), goals, resource base, and the agency necessary to deploy resources in the service of political goals - likely to target and/or attack US citizens or interests. While there has been 
some qualitative research on why groups might want to target the West or the United States (Cronin, 2003; Mousseau, 2002) and on particular groups that seek to target the US (Fishel, 2002; Laqueur, 2004; Wiktorowicz \& Kaltner, 2003), no study has focused quantitatively on features that make it more or less likely that an organization will choose to target or attack the United States. Indeed, we have been able to find only one quantitative analysis that examines any factors that might increase the chances a group or individual will target or attack the United States, its citizens, military, or economic interests (Sobek \& Braithwaite, 2005). The extant qualitative literature identifies American corporate, cultural, and military presence and influence on countries as a motive factors for attacking the United States (Hoffmann, 2002; Jervis, 2003, 379). Islam and anti-globalization movements have also been suggested as key motivators for such attacks (Ajami, 2001, 4; Cronin, 2003, 34).

In this article we weigh these organizational and environmental factors to identify those that increase the likelihood that a terrorist organization based outside the US will target or attack the United States and its interests at home and abroad, with specific aim of providing a model that can (within the limits of our data) predict which organizations are likely to target and/or attack US interests in the future. We restrict our model to organizations based outside the US so that we may focus on how US interactions with the world affect the behavior of terrorists that have no intrinsic stake in US domestic policy choices.

To explore those factors that make it more likely that a terrorist organization will target and/or attack the United States, we develop a model using data from the National Memorial Institute for the Prevention of Terrorism's (MIPT) Terrorism Knowledge Base, the only publicly available dataset of domestic and international terrorism that is comprehensive and global and includes data on organizational factors. ${ }^{2}$ The model focuses on two dimensions. The first is motivation. Some organizations have stronger reasons for seeking to harm US interests. The 
theoretical literature and qualitative studies provide a panoply of possible motivations; we will test several of them. The second dimension is capability. A great many terrorist organizations profess anti-Americanism in their rhetoric, but many are resource constrained when they attempt to act on their bile. The combination of motivation and capability is central to our model.

As is true of much quantitative research on terrorism, there are important temporal and data constraints on this study, especially given the cross-sectional design, eight year span, and number of unclaimed attacks. However, we believe that this is the best data available and is worthy of investigation.

\section{Motivations for Targeting and Attacking America}

Despite the tendency after September 11 to view the US as besieged by terrorist organizations, for most terrorist enterprises there is no self-evident rationale for targeting or attacking US interests. Most terrorist organizations are focused on conflicts and controversies that are local in nature and have drawn little if any attention from US political, military, or economic institutions. In fact, there are only 48 (12.2\%) organizations in the MIPT database that list the US as either their primary target or their primary international target (MIPT, 2006). MIPT's event data identifies $70(17.7 \%)$ organizations that have attacked US interests over the period 1998-2005 (MIPT, 2006). Nevertheless, the extant literature identifies at least three major motivations for targeting and attacking the US and it interests.

Before delving into the literature, it bears examining for a moment the distinction between targeting and attacking. The two concepts are not substitutes for one another. One is an expressed intention; the other is an expressed behavior. The behavior does not need to have an expressed motivation as an antecedent. For instance, some organizations are motivated by broadbased ideologies such as communism or socialism may attack US interests because those 
persons, places, or things are viewed as symbolic or actual manifestation of the objectionable features of the political or social environment. Other organizations may attack US interests because US actions support the objectionable entities they wish to influence (for instance, when the US is attacked because it supports Israel). Thus organizations may attack US interests while primarily targeting something or someone else. As the discussion below suggests, we believe that the factors that lead organizations to target the US are largely parallel to those that lead to actual attacks. Where we believe a discrepancy exists, we will highlight it. The statistical tests that follow allow us to model separately the propensity to attack and to target US interests.

Islam. The motivation that has garnered the most attention since September 11 is undoubtedly the various forms of radical Islam that terrorist organizations have adopted as their guiding ideology. It has been argued that for particular types of radical Islam, violence and specifically violence against civilians is seen as a religious obligation because Americans (along with Israelis) are "people of war” who “... oppress and attack Muslims” (al-Qaeda, 2002) in Afghanistan, Iraq and elsewhere. Moreover, Israel is portrayed as an implementer of an American policy of attacking the Muslim world. The conflict in Palestine is viewed as only one of many strategic components designed to support US aggression. As a result, adherents of this line of reasoning argue that one may use the same tactics and strategies against both (Wiktorowicz \& Kaltner, 2003, 82-83). “As a “crusader nation,” Americans - both civilian and military - are viewed as legitimate targets (Wiktorowicz \& Kaltner, 2003). We quote the following Al Qaeda statement at length, for it provides a strong rationale for targeting American interests and civilians given the perception of American behavior:

We say that the prohibition against the blood of women, children, and the elderly is not an absolute prohibition...

First: It is allowed for Muslims to kill protected ones among unbelievers as an act 
of reciprocity. If the unbelievers have targeted Muslim women, children, and elderly, it is permissible for Muslims to respond in kind...

Second: It is allowed for Muslims to kill protected ones among unbelievers in the event of an attack against them in which it is not possible to differentiate the protected ones from the combatants...

Third: It is allowed for Muslims to kill protected ones among unbelievers on the condition that the protected ones have assisted in combat ...

Fourth: It is allowed for Muslims to kill protected ones among unbelievers in the event of a need to burn the strongholds or fields of the enemy...

Fifth: It is allowed for Muslims to kill protected ones among unbelievers when they are using heavy weapons that do not distinguish between combatants and protected ones...

Sixth: It is allowed for Muslims to kill protected ones among unbelievers when the enemy is shielded by their women or children. ...

Seventh: It is allowed for Muslims to kill protected ones among unbelievers if the people of a treaty violate their treaty and the leader must kill them in order to teach them a lesson. ... (al-Qaeda, 2002). ${ }^{3}$

We would note that MIPT currently lists at least 33 allied affiliates of Al Qaeda all of which are Islamically-inspired and view Al Qaeda as a peer, if not a controlling authority. The manifesto outlined above provides at least behavioral guidance to these affiliates.

Finally, the view that America is occupying the holy land of Arabia creates a situation where adherents may frame attacks against the U.S. in religious terms (Lewis, 1998, 19; Mockaitis, 2003). Talhami argues that this religious frame is strengthened by the existence in the "Muslim and Arab world [of] a deeply ingrained perception of their victimization by the 
Christian West (Talhami, 2003, 115)." Targeting and attacking America serves both religious and retributive ends. For these reasons we hypothesize that those organizations with an Islamic ideology will be more likely to target and attack the United States.

\section{Hypothesis 1: Organizations with Islamic ideologies will be more likely to target and to attack the United States.}

US military presence. We should note, though, that this argument - anger that is inspired by US influence on an organization's host country - is not inherently tied to Islam. Ajami (2001) and Wiktorowicz \& Kaltner (2003), for example, argue that many in the Arab world are angry at US support for Israel and for the dictators in their countries. Many terrorists were angry at America because they “....were sure of America's culpability for the growing misery in their lands. They were sure that the regimes in Saudi Arabia and Egypt would fall if only they could force the United States to cast its allies adrift (Ajami, 2001, 4)" - an assumption thorough invalidated by the recent "Jasmine Revolution." This suggests arguments about the motivation for terrorism that is based not so much on particular ideologies or world views but on specific grievances about American behavior - particularly American military, economic, political, and cultural penetration of other countries.

If true, this particular motivation presents a significant policy conundrum for the United States. Economically, the United States is a key motor of the international economy and one of the major beneficiaries thereof. Strategically, since the close of the World War II the United States has viewed open economic and trade relationships as a key to preserving the peace through the fostering of economic and political integration that makes conflict costly. This dominance makes enemies both because of what the United States does and what states want the US to do (Lewis, 1998, 19). Sobek and Braithwaite $(2005,135)$ have argued that as American 
dominance in this system increases, terrorism against the United States increases. Because of American power, “...revisionist groups cannot alter American policy through conventional methods. ... [If] there exists no prospect that their position of inferiority will change, then [the groups] might plausibly resort to terrorism (Sobek \& Braithwaite, 2005, 136).”

In many cases "American interests" implies a strong investment in the economic and political status quo. The United States is often “...shoring up the stability of regimes around the world (Juergensmeyer, 2003, 183)" in the service of said status quo. Yet US efforts are often made in circumstances where the ruling regime is actively opposed by violent internal forces that are seeking to upset the status quo. One specific policy that has been identified as a goad to attacks by Pillar (2001) and others (Ajami, 2001, 5; Jervis, 2003, 379; Johnson, 2002, 25; Pape, 2005) is the presence of US military forces overseas: "The mere presence of U.S. contingents overseas is an ingredient in terrorist resentment against the United States (Pillar, 2001, 61).” With more then "800 Department of Defense installations (Johnson, 2002, 25)" overseas, US military presence may be generating a great deal of resentment. In addition to creating a motivation to target US interests, the stationing of US troops abroad provides convenient military and civilian installations and a regular supply of US citizens or foreign national affiliates that can be attacked without traveling to America (Pillar, 2001, 69).

\section{Hypothesis 2: Organizations in countries with a significant United States troop presence (more then 2,000) are more likely to target and to attack the United States.}

On the other hand much of the literature on the effect of United States troops focuses on the places where America is supporting authoritarian regimes (Pape, 2005). Thus we posit that the issue may not be military presence by itself but presence in countries that are not democracies. Thus: 


\section{Hypothesis 3: Organizations based in countries with significant United States troop presence (more then 2,000) that are not democracies are more likely to target and to attack the United States.}

Western economic and cultural influence. While American military presence may be a motivator, Western economic influence has also been seen as a motivator for international terrorism. Globalization has opened tremendous opportunities for Western businesses while simultaneously generating new grievances against the US (as the central symbol of Western economic power) and new opportunities to act on those grievances (Cronin, 2003, 30). Cronin, for example, argues that:

"Even though the newest international terrorist threat, emanating largely from Muslim countries, has more than a modicum of religious inspiration, it is more accurate to see it as part of a larger phenomenon of antiglobalization and tension between the have and have-not nations, as well as between the elite and underprivileged within those nations. In an era where reforms occur at a pace much slower than is desired, terrorists today, like those before them, aim to exploit the frustrations of the common people (especially in the Arab world) (Cronin, 2003, 35).”

Thus Islamic motivations may be separable from economic ones.

As noted, "anti-globalizers" often identify the United States as the key enemy and as the face of globalization itself. When compared to the developing world America consumes a disproportionate share of the world's resources (Glynn, 2005, 114). For cultural reasons, both Leftists and Islamists view America as the source of a global threat (Pillar, 2001, 63).

We should note though that globalization's effects - or at least its economic effects may have both negative and positive features. Li and Schaub (2004) have found that foreign 
direct investment and trade have either no effect or a weak negative effect on whether a country will host international terrorist events. Nonetheless, the literature strongly suggests that a large US economic presence will encourage terrorist attacks against United States targets. In practice, this is a problematic hypothesis to test.

Finally, there is a logical relationship between attacking US interests and greater global economic involvement. In general, the more global the country's economy, the more US targets one may find in those countries precisely because the US is such a large global economic presence. Collectively, then:

\section{Hypothesis 4: Organizations from countries with higher exports to the world are more likely to target and to attack the United States.}

Another motive factor may be US cultural penetration in much of the world through globalized commerce and media. One of the products of globalization is that American media from music to movies - is now available everywhere in the world (Juergensmeyer, 2003, 183). Globalization facilitates a clash of cultures that was not possible before, which in turn creates a dangerous sense of cultural vulnerability that motivates violence against the United States (Mousseau, 2002). In its more extreme form, the cultural threat may be transmuted into a sense of existential threat (Glynn, 2005, 121). The deleterious effects of exported American media and culture are often brought up by terrorists themselves as one of the reasons they target the United States (Judge, 2002, 7). The economic and cultural threat, of course, do not need to be seen as separate, but can easily be viewed as a combination that threatens to swamp the way of life of groups antagonistic to American dominance (Hoffmann, 2002, 112).

Attempting to operationalize America's cultural penetration of a country has proven to be particularly challenging. There is no ready index available, and we considered everything from 
US movie revenues to iTunes sales. In the end, we have fallen back on whether a country has a McDonalds restaurant as a proxy for United States cultural penetration. Many people see the Golden Arches in just this way: as a symbol of American cultural imperialism (Watson, 1997). As Pillar argues “A branch office of Citibank or a McDonald's restaurant just happens to be among the more accessible, tangible, and attackable manifestations of a much larger U.S. dominated culture and economy that is the main object of scorn and anger (Pillar, 2001, 63).”

Hypothesis 5: Organizations from countries with McDonald's restaurants are more likely to target and to attack the United States

\section{Capabilities for Attacking America}

While the terrorism literature has focused on ideologies such as Islam as a key motivation for terrorist organizations, scholars of social movements have emphasized capabilities. There are at least two variants of this line of argument. The first identifies capabilities as a direct effect. Movements that are able to mobilize resources are more likely to emerge and "succeed" (McCammon, Granberg, Campbell, \& Mowery, 2001; McCarthy \& Zald, 1977). There are obviously many types of resources that are needed to maintain a terrorist enterprise, including financial assets, technical expertise, and access to restricted places, materials, and knowledge. However, we - like Boyns and Ballard $(2004,14)$ - argue that "human capital" is essential. It is the talent, expertise, and social connections (Bienenstock \& Sageman, 2005) of individuals involved in the organization that allow it to be successful at gathering other resources that are needed to sustain itself. Ideally, we would have a detailed "roster" of an organization's membership that specified its array of talents and expertise. In the absence of such detailed knowledge, we believe a useful proxy is the estimated size of the organization's membership. The larger an organization becomes, the more likely that its membership includes individuals 
that are (a) skilled at the methods of death and destruction, (b) capable of raising and managing money, and (c) possessed of access to restricted information, places, and materials. In short, bigger organizations should be more capable.

The second variant of the capabilities argument focuses on sustainability and resource gathering. As Crenshaw points out, anti-American terrorism can result not just from what the terrorists want from America but how they hope attacking America will play amongst their potential supporters. "Extremist religious beliefs play a role in motivating terrorism, but [terrorists] also display an instrumental logic (Crenshaw, 2001, 425).” Crenshaw goes on to argue that organizations attack America because it brings them popular support and attention while potentially provoking useful counter-actions by the US itself. Ideally, attacking Americans might lead the US to abandon the host government. Failing this, an almost equally useful outcome would be a US intervention that generates propagandistic and/or material benefits (Crenshaw, Dugan, \& LaFree, 2006). ${ }^{4}$ Similarly, Doran $(2002,46)$ argues that Bin-Laden “...had no intention of defeating America. War with the United States was not a goal in and of itself but rather an instrument designed to help his brand of extremist Islam survive and flourish among the believers." Attacking the US helps to generate members and resources.

There is a catch, however: Attacking a colossus is not cheap or easy. Attacking US interests to gain resources and members itself requires resources. For instance, Al Qaeda's 1998 attacks on two US embassies in Africa helped to make Al Qaeda a global brand-name. Yet the attack involved at least 21 active members (see United States of America vs. Usama Bin Laden S(9) 98 Cr. 1023 (LBS) ) across several countries. The old saw that it "takes money to make money" applies to terrorism, too. For these reasons, we link size to the likelihood of attacks on US interests.

Hypothesis 6: Organizations with larger memberships are more likely to target and 


\section{attack the United States and its interests.}

Membership size is not the only factor that may matter. Indeed, a more central issue may be the possession of resources that allow an organization to reach out internationally. As alluded to above, access to countries and places where Americans or American interests are at risk is critical - as the Embassy bombing plot again demonstrates. Most organizations lack regional much less global scope in their operations. However, they may be able to "borrow" capabilities via alliance relationships to perpetrate an attack. The most extreme example of this was the Lod Airport attack, where the Japanese Red Army attacked on behalf of the Popular Front for the Liberation Palestine (PFLP) (see, for instance, Steinhoff 1976). Any given organization may lack the resources necessary to attack American interests; however, they may be able to leverage resources from other organizations to "fill the gaps."

Targeting may be similarly influenced by alliance connections. First, organizations are less likely to advertise a desire to attack US interests in the absence of resources needed to do so successfully - or at all. Expressed intentions to attack draw unwanted scrutiny from US authorities - and from publics from which the organization is recruiting. No one wants to join an ineffectual organization.

Second, alliances may also mold the expressed targeting preferences of member organizations. Alliance ties are a risk for licit organizations; they are much moreso for organizations that can be disbanded and their members arrested for contacts with prohibited entities. Trust is at least as important in terrorist undertaking as in licit ones (see Erickson, 1981, for a broader discussion of trust in secret societies; see also Krebs, 2002). To gain entre to regional or global terror syndicates, the price of admission may be adherence to a common set of beliefs and ideals - a form of mimetic isomorphism (DiMaggio \& Powell, 1983) across norms rather than structures. 
Thus we believe that alliance connections are a key resource for terrorist organizations (Bienenstock \& Sageman, 2005). Network connections can provide essential information, goods and other kinds of assistance which may be crucial when targeting the United States. The case for alliance ties as a key to attacking US interests is straight-forward; the case for targeting is somewhat more abstract but we believe potent nonetheless.

\section{Hypothesis 7: Organizations with many network connections are more likely to attack and to target the United States}

To isolate the effects of our explanatory variables, our models include a series of controls. Because imports from the US tends to be correlated with GDP, our models include controls for host-country GDP (in purchasing power parity terms). Additionally, host-country military expenditures may tend to dampen the opportunities to attack US interests in the host country and may reduce all terrorist activity, so we have also included a measure of military expenditures per capita. Our previous research suggests that state sponsorship of a terrorist organization and past experience with terrorism may condition the probability of targeting or attacking the United States <author citations>. Finally, civil conflict (either solely internal or internal and internationalized) may help to foment other forms of violence and conflict - or in this case may draw attention to the strife at hand and away from attacks on the US. Thus we also include a control for the number of years the host country experienced internal or internal and internationalized conflict during our study period.

\section{Data $^{5}$}

Data for this study was derived from several datasets. Our primary source for the state sponsorship, Islamic ideology, alliance connection count, and our dependent variables

(“targeting" and "attacking”) was MIPT's Terrorism Knowledge Base (TKB) (MIPT, 2006). 
Using the data available as of January 17, 2006, we were able to assemble information on 395 of the 499 organizations that had committed at least one terrorist incident between 1998 and 2005. We dropped organizations based in the United States, leaving 387 entries in the dataset. Dummy variables were created from the information provided on the group pages of the TKB website for Islamic ideology, state sponsorship, and targeting of the United States.

Our targeting dependent variable was constructed by analyzing the MIPT pages for each organization to discover whether the organization listed the United States as a primary target or primary international target. Coders read the description of the organization and its intentions and goals. When MIPT's information was insufficient, coders sought other sources, including organizational web pages, journalistic accounts, and scholarly papers.

Our attacks dependent variable was constructed using the events dataset in the MIPT system. MIPT's "advanced search" capability allowed users to extract attacks that were coded as being a "US Attack" (see http://www.tkb.org/AdvancedSearch.jsp), meaning the attack was on US citizens, installations, or interests world-wide. As of September 27, 2007, there were 454 US attacks during the period 1998-2005. Of these, 192 were attributable to organizations in our dataset; 259 were attributed to "Unknown Group"; three more were attributed to organizations for which we had no information. Again, "attacks" conforms to the MIPT definition, which focuses on acts perpetrated against civilians. MIPT classifies attacks into 20 categories, including attacks on "military and "government" targets. Of the 192 attributed attacks, 4 were against military targets and 21 against government targets. However, these attacks were clearly terrorist events. For instance, one "military" attack was against sailors hiking a volcano in the Philippines while out of uniform. The attack report suggests that the perpetrators were unaware that the victims were military members. Similarly, "government" targets were usually - but not always soft targets, such as town halls (the exceptions were, for instance, embassies). 
TKB's data on membership size was incomplete for a number of organizations, so we asked a panel of experts at the Monterey Terrorism Research and Education Program at the Monterey Institute of International Studies (MIIS) to provide a best estimate of size based on a series of intervals. After combining data from MIPT and MIIS, there were still 77 organizations for which we had "low-confidence" size data. That is, our data on size was for these organizations is less complete than we desired. For almost all 77 we were sure they were small but were not comfortable coding them explicitly in our scheme. Thus we coded these organizations as having size "0." Table 1 presents our coding scheme for size. Table 1 summarizes the coding system and number of organizations that fall into each category.

Table 1 about here

To capture the effect of organizational alliances, we coded TKB's 22-item "related groups" system into six codes that ranged from "target" to "affiliated wing." We then used UCINET 6 (Borgatti, Everett, \& Freeman, 2002) to count the number of "positive" (i.e., suspected alliance, alliance \& rivalry, confirmed alliance, and familial) relationships each organization has. In social network parlance, we calculated the organization's simple degree the number of positive, direct alliance relationships that each organizations has.

For our country context data, we relied on several other databases. Each of the country variables were coded for the host country of the terrorist organization. If the organization has more than one host country we coded for the most important one (i.e., the one where the most members are located or where the most attacks occur according to MIPT). For modeling of economic interaction with the world, we experimented with three different measures: exports or imports to/from the world, exports or imports to/from the US, and a composite measure of trade to GDP. For data on US bilateral trade we used data compiled by Robert C. Feenstra at the 
National Bureau of Economic Research (see www.internationaldata.org) (Feenstra, 1996, 1997, 2004a, 2004b). For data on global trade, we used the Annual Totals Table for Imports and Exports available from the United Nations Statistics Division, International Merchandise Trade Statistics Section (IMTSS) (see http://unstats.un.org/unsd/trade/imts/annual\%20totals.htm). Finally, we also used the Penn World Tables (version 6.2) OPENC variable (Heston, Summers, \& Aten, 2006), which is calculated as exports plus imports divided by GDP. For US exports/imports and OPENC we used data from 1997. The UN data was only available for 2000 during our study period, thus that is the year we used. As is common, we used a natural log transformation of the trade variables in order to make the data series less skewed. For our final models, we selected the UN export variable because it had the best fit to the data, based on AIC, BIC, and pseudo- $\mathrm{R}^{2}$. However, we should also note that the US trade and OPENC variables were found to be unrelated to targeting or attacking US interests. To see the alternative modeling efforts, see Table A.5 - A.14 in the downloadable Appendix (available at <URL here>).

The variable for democracy was created using the POLITY IV dataset (Marshall \& Jaggers, 2003). The widely-used POLITY2 measure of regime type varies from 10 (strongly democratic) to -10 (strongly autocratic). For this variable we also used data from 1997 . We coded an organization's host country as non-democratic if it scored 5 or less on the POLITY2 measure.

The location of McDonalds restaurants was secured from a spreadsheet prepared by McDonalds Corporation that reported the number and location of restaurants world-wide in 1998 and 2003. Following our earlier logic, we used the presence or absence of one or more restaurants in a given country in 1998 as our indicator.

Data on United States troops abroad were taken from work by Tim Kane for the Heritage Foundation (Kane, 2005). This data allowed us to observe the maximum and average number of 
US troops stationed in each host country during our period. We experimented with a variety of cutoff values during our modeling, including 100, 1,000, 2,000, and 5,000. The downloadable appendix reports findings across these four levels and across the average and maximum standards. Our modeling indicated that (1) the fit statistics (AIC, BIC, and pseudo- ${ }^{2}$ ) almost uniformly found that the maximum standard dominated the average standard; (2) using the 2,000 standard was superior to most others, but generated almost identical results to the 5,000 standard; and (3) there was some sensitivity at lower thresholds when Iraqi and Afghani groups are excluded (we will say more about this below). For these reasons, we settled on a cutoff of a maximum deployment of at least 2,000 troops during the period 1998-2005.

Data on the presence of civil strife (either domestic or internationalized) was extracted from the Uppsala Conflict Data Program / International Peace Research Institute, Oslo (UCDP/PRIO) Armed Conflict Dataset, 1946-2005 (Gleditsch, Wallensteen, Eriksson, Sollenberg, \& Strand, 2002; Harbom, Högbladh, \& Wallensteen, 2006; Uppsala Conflict Data Program (UCDP) \& Research Institute - Oslo (PRIO), 2006). Our variable counts the number of years of civil strife reported in the dataset (type 3 and 4 conflicts) for our study period.

Data on military expenditures was derived from the Correlates of War (COW) Project (Correlates of War II, 2004; Singer, 1988) dataset. COW contains a measure of military expenditures (milex) and a measure of total population (tpop). We divided milex by tpop as reported for 1997 to construct our variable.

Per capita Gross Domestic Product (GDP) data was extracted from the International Monetary Fund's World Economic Outlook databases system, April 2007 Edition (International Monetary Fund, 2007). The data was extracted for $1997 .^{6}$ 
After experimenting with several thresholds for "inexperience" with terrorism, we have found in this and other work < author citation> that perpetrating three or fewer attacks is a sensible cutoff, which we will use here as well.

Finally, the interactive variable on large US troop presence and "not democracy" was created in the standard, multiplicative fashion from our democracy and troop presence variables. Table A.1 in the Appendix presents descriptive statistics for each variable.

\section{Who Targets and Attacks America?}

Of the 387 non-American organizations for which we have complete data during the period 1998-2005 (MIPT, 2006), 43 listed the US as their primary or primary international target while 70 organizations have attacked US interests. The organizations and their host countries are listed in Table A.2 and A. 3 of the Appendix. Table 2 summarizes the characteristics of those organizations. Groups that attack US interests tend to somewhat older, less likely to be inspired by Islam, and much less likely to be hosted by a country with a large US military presence. Iraq is the modal host country for organizations that target the US ( 21 of 43), whereas Greece is the modal host for organizations that have perpetrated attacks (16 of 70). Twenty-seven countries hosted groups that conducted one or more attacks on US interests; only 11 countries host organizations that actively target US interests.

\section{Table 2 about here}

\section{Analysis}

Our dependent variables are both dummy variables. For targeting, an organization is assigned a one if the organization targets the United States or American interests abroad and zero otherwise, as reported in the MIPT database. For attacking, the organization was assigned a one if MIPT listed at least one "US attack" during our study period. For both dependent variables we 
used logistic regression with clustering on the host country of the organization to analyze the data (Rogers, 1993). Table 3 reports our results.

\section{Table 3 about here}

For both targeting and attacking we report models with and without the democracy / large US troop presence interactive. The pseudo- $\mathrm{R}^{2}, \mathrm{AIC}, \mathrm{BIC}$, and Wald $\chi^{2}$ all suggest that our "targeting" models fit better than the "attacking" models. To evaluate the possibility of multicollinearity in our findings we have examined both a correlation table for our variables and the variance influence factor (VIF) metric generated from a series of linear probability models see Tables A.25-A.27 in the Appendix. Our analysis suggests the results are not affected by multicollinearity.

Starting with motivation, per Hypothesis 1 Islamic ideology is weakly related to targeting and attacking American interests, with three of the four models significant at the $10 \%$ level only. Islam is an overt motivator - and one that we would hasten to add appears to have become more potent toward the end of our study period. Nevertheless, Islamic organizations are located in countries that have, relatively speaking, fewer US interests and installation, making it more difficult to stage an attack. This could account for the difference, though we suspect the strong effect for alliance connections has actually accounted for most of the "Islam" effect - see below.

Turning to Hypothesis 2, only the targeting model without the interaction between democracy and troop presence finds a significant effect. Simply put, US troop presence only seems to matter when it occurs in the context of an authoritarian government. This is not due to small numbers in this particular joint category. There are 55 organizations that are hosted in democratic countries with a large US military presence. Spain, Turkey, Italy, Japan, and Germany are all home to large US troop concentrations and terrorist organizations that were 
active during the period 1998-2005. Nevertheless, these groups did not show a particular inclination to strike American interests, despite the troop presence. We should note that had we done this analysis for the period of the 1970's and 1980's these results would likely have been different given the activity of several Marxist groups.

However, per Hypothesis 3, we did find a very large relationship between US troops in non-democratic states and the proclivity to target and to attack US interests. Forty-seven groups fall into this category. Not surprisingly, most of these groups are located in Afghanistan and Iraq - the locus of conflict in the later part of our period. However, this group also includes organizations based in Saudi Arabia, Egypt, Peru, and Europe.

To determine whether our findings were driven by the Iraqi and Afghani organizations, we ran a set of separate regressions without these groups. ${ }^{7}$ Our findings are generally the same, with one exception: the civil war control falls out of the targeting regression because it is perfectly correlated with not targeting the US. We did find that if we lowered the troop threshold to 1,000 or 100 troops and ran the models without Iraqi or Afghani organizations that we failed to find the interaction significant. For this reason we chose the higher threshold as a more general finding.

Turing to Hypothesis 4, the evidence on economic integration with the global economy was contrary to our expectation. The export measure is significant in all models at the $5 \%$ level but the sign is negative, suggesting that economic integration with the West decreases, not increases, the probability of targeting or attacking the US, contrary to our expectations. As a host country's stake in the global economy grows, its terrorist organizations are less likely to attack US interests.

Our findings on the McDonalds variable (Hypothesis 5) are most interesting. In the targeting models, we find the "McDonalds effect" to be precisely the opposite of what we 
expected. The effect is negative and statistically insignificant. If anything, cultural penetration tends to reduce the probability of terrorist organizations expressing an intention to harm US interests.

Yet when we turn to actual attacks, the effect is positive and significant at the $5 \%$ or even $1 \%$ level. What accounts for the discrepancy? Probably access. As Pillar (2001) suggests, countries that host a McDonalds are likely to have more US installation, citizens, and civilian government employees that are vulnerable to terrorist attack. US cultural embedding tends to inoculate (if it matters at all), but also tends to spread the risk as more citizens and economic interests choose to locate in disturbed locations.

Turning now to our arguments on capabilities, our findings conform to two of our three $a$ priori hypotheses. Contrary to our expectations in Hypotheses 6, there is no relationship between organizational membership and propensity to target or attack the US. Our previous work < author citation> found a strong relationship between size and propensity to kill, but the pattern does not hold for targeting or attacking the US. There is some chance our findings regarding membership could be affected by the number of "low confidence" observations. However, (a) our regression on a reduced dataset (one that excluded the low-confidence variables) failed to find a relationship, and (b) a check for sensitivity to inclusion or exclusion of the organizational membership variable found in Table A.28 of the Appendix shows that inclusion changes the other results very little. Thus we find no evidence to support Hypothesis 6.

Per Hypothesis 7 we did find that alliance connections are positively related to targeting and attacking the US. Being allied with others provides both the capabilities needed to attack US interests and connections to like-minded others who may influence targeting decisions. Our stochastic modeling of network relationships in this dataset has found that Islamic groups are far more likely to make connections with one another (see <author citation>). Islamic organizations 
have almost twice as many connections, on average (1.08 versus 2.15$)$, as non-Islamic organizations. The "Islam" effect may express itself as a willingness to make more and more productive alliances with like-minded entities.

Briefly turning to our control variables, we note three findings. First, state sponsorship has no explanatory power in our models. The estimated coefficients, however, are negative, as expected. As Simon and Benjamin (2001) suggest, state sponsorship tends to put a brake on efforts to target or attack US interests. Second, inexperienced groups are far less likely to attack US interests, but inexperience has no relationship to targeting choices. Third, years of civil war is negative and statistically significant in the targeting model and negative and statistically insignificant in the attacking model. This suggests that civil conflicts may make groups inwardly directly. Why attack US interests when there are many targets and issues at home?

To get a sense of the size of effects, we calculated the probability of targeting or attacking the US across our four models for the variables that are significant - see Table 4. These "simulations" find the change in probability of targeting or attacking by varying (a) the status variables from 0 to 1 or (b) varying the continuous variables by one or more standard deviations around their mean while holding all other values of the independents at their means. For these calculations, we used the "prvalue" command in Stata, available from www.indiana.edu/ jslsoc / spost.htm (for technical details, see Long, 1997; Long \& Freese, 2003).

\section{Table 4 about here}

The largest effect by far is from the presence of US troops in a non-democratic country. Organizations were more than 42 times more likely to target US interests and nearly 5.5 times more likely to attack US interests under these circumstances, as compared to an "average" organization (all else held constant). The effect of alliance connections on both targeting and 
attacking is about the same: a two standard deviation change in connections doubles the chances of targeting and attacking. The presence of a McDonalds restaurant increases the chances of an attack by 6.6 times in the model that includes the troops/non-democracy interactive as compared to countries without the Gold Arches. Though the absolute changes are small, organizations hosted by countries that are one standard deviation above the mean on trade are between $1 / 3$ and 1/2 less likely to attack or target US interests. Finally, inexperience sharply decreases the chances of attacking US interests while civil strife sharply decreases the chances of a group targeting the US.

Drawing together our findings, the organizations most likely to target US interests are those organizations that are (1) Islamic in their inspiration (though equivocally so) (2) based in an authoritarian-leaning state with a large US military contingent on the ground (3) relatively well connected to other terrorist organizations and located (4) in a country not experiencing civil strife but also (5) not well connected to the global economy. The organizations most likely to attack American interests are (1) based in a country with a large US military contingent and an authoritarian-leaning state that is (2) relatively well connected to US cultural institutions (which generate more targets to attack) and (3) relatively poorly connected to the global economy; such organizations tend to be (4) experienced with terrorism and (5) relatively well-connected to peer terrorist organizations. Troop presence in non-democratic states and alliance connections are the only drivers that have a consistent sign and significance across our models.

\section{Implications for policy and research}

Our findings raise interesting questions about the focus of American counter-terrorism efforts and the repercussions of America's policy choices. Some have argued - Robert Pape (2005) maybe most prominently - that the response to terrorism should be a general withdrawal 
of US troops from around the globe. Similarly, Betts cites the argument from Sheik Salman alAwdah that ... "if America just let well enough alone, and got out of their obligations overseas ... no one would bother them (Betts, 2002, 34)." Some advocate a similar but less extreme line, with Eland recommending "military restraint":

If the U.S. government adopted a policy of military restraint overseas, in the long term the number of devastating, and potentially catastrophic, terrorist attacks against the United States...could be reduced significantly. Even if some remaining terrorist incidents can be attributed to a hatred of U.S. economic power, individual freedom, or culture, those national attributes are much harder and more costly to alter, and it would be undesirable to do so. It is much easier (and after the Cold War, relatively painless) to change U.S. foreign policy than it is to change the American way of life (Eland, 1998, 6). Our findings suggest that there are repercussions for US policy, and that some organizations bear much closer watching then others. When US troops are quartered in countries where authoritarian governments rule, US interests become far more likely to be targeted and attacked. Moreover, such basing choices may place US interests globally at greater risk, for organizations that hail from countries where a relatively large number of US "boots" are on the ground are much more likely to target US interests.

Second, our findings suggest that economic and cultural engagement may well be an effective strategy for ameliorating terrorist threats. But there is a paradox here. The countries that "grow" terrorist groups likely to target America are places that are less thoroughly integrated with the West economically and culturally. This suggests that part of the reason to target American interests is to keep their host country out of the Western economic and cultural orbit. Terrorist organizations may well worry that once citizens are integrated into the Western cultural and economic system, the creation of merchant and political classes with a stake in keeping the 
dollars flowing will inhibit their organization's financial and membership drives.

Further deepening the paradox is our findings on attacks. Though engagement and economic participation in the world economy may be a long-term antidote to terrorism and terrorist attacks on the US, in the short run greater engagement simply generates a larger menu of targets for those seeking to harm US interests.

How to square this circle? Programs of "democratization" as currently pursued by the United States and other western countries - top down exhortations - may look like another form of external intervention that have both political and cultural significance. Similarly, strategies that focus on elections may also be misplaced. As Robert Putnam has shown in several contexts (Putnam, 1993, 2000), one precursor to strong, functioning democracy is development of a broad-based civil society and a middle class through, for instance, micro lending and ongoing dialogue between factions. Building from the ground up may generate outcomes that are locally based and thus have a better chance of being sustainable.

Finally, our findings on alliance connections have implications for counter-terrorism policies and practices. Alliance connections appear to be potent drivers of behavior. Our work has found alliance connections help to explain targeting and attacking America, pursuit of weapons of mass destruction, lethality of terrorist organizations, and proclivity to attack airports or airplanes <author citations>. How are alliances made? How are they disrupted? While we know a fair amount about building what we refer to as tactical networks (e.g., networks of persons to do bad acts - see, for instance, Sageman, 2004), our knowledge of organizational network building is limited at best (but see Zanini \& Edward, 2001). Our work leads us to believe that these organizational alliances are built over time and between trusted individuals in organizations. The key is discovering organizations that may have a terroristic bent early before they become trusted by like-minded others. Trust takes time to build; disrupting it 
requires interruption of patterns of interaction, especially since trust is most reliably built through repeated face-to-face interactions (see Burt, 2005 - especially chapter 3). Finally, the literature on licit organizations tells us that boundary-spanning requires special talents (see, for instance, Tushman and Scalan, 1981 and Bouty, 2000).

What do these assumptions add up to? First, surveillance, interdiction, and detention of certain kinds of suspected terrorists can matter quite a lot. The boundary-spanners in question are likely to be older, more educated, longer-tenured in the organization, and closer to the senior personnel, just as in many small to medium for-profit and non-profit organizations. Jailing every person found to have spent time in a terrorist training camp is far less productive than finding persons who are likely to communicate with others who are positioned to broker relations between organizations.

Second, one easy way for alliances to grow is through fractionalization of existing organizations. The proliferation of splinters creates the basis for future alliance - even if the splinter was created by internal disagreements. One fruitful approach is to prevent rapprochement between factions by co-opting one side of the dyad. The British decision to work with the IRA, for instance, may have helped to drive a wedge between the IRA and factions such as the Real IRA.

Finally, it is clear that like cancer, early detection of terror organizations is critical. Time builds trust, alliance ties, membership, and experience - all factors in either attacking US interests or killing large numbers of people <author citation>. A more proactive approach to counter-terrorism would focus on the path from licit or quasi-licit group to terrorist organization. Finding reliable precursors or patterns of development is only beginning (see, for instance, <author citation>) but must be a focus of future work.

\section{Conclusion}


While we believe that our dataset is the most complete resource currently available, there are several key limitations that should be highlighted. Any study of terrorism is bounded by the unknown. The organizations in our dataset account for slightly more than half of all global terrorist fatalities between 1998 and 2005. The unclaimed fatalities may well be largely the responsibility of individuals or transitory groups that would not fit the standard definitions of “organization," but we have no way of knowing. Of the 499 organizations that have committed an act, MIPT had no information on 104 of them. Many of these organizations existed for brief periods of time, and others may be temporary splinters of existing organizations. If so, these omitted "entities" may also lack sufficient cohesion to be considered organizations and thus belong in a different study. Additionally, some variables are notoriously hard to code accurately, even for the organizations we know well. For these reasons, care should be taken generalizing beyond the period we have studied.

Nevertheless, we believe this to be the most comprehensive and in-depth study of factors that lead organizations to target and attack the United States ever attempted. It provides a probabilistic model of terrorist organizational behavior that can be used to identify organizations that due to their ideology, alliance connections, character of their host country, and that host country's relationship to the US military and culture bear greater scrutiny and vigilance.

\section{Bibliography}

Addison, T., \& Murshed, M. (2005). Transnational terrorism as a spillover of domestic disputes in other countries. Defence and Peace Economics, 16(2), 69-82.

Ajami, F. (2001). The Sentry's Solitude. Foreign Affairs, 80(6), 2-16. 
al-Qaeda. (2002, April 24, 2002). A Statement from Qaidat al-Jihad Regarding the Mandates of the Heroes and the Legality of the Operations in New York and Washington. Retrieved July 27 2006, 2006, from http://mepc.org/journal_vol10/0306_alqaeda.asp

Betts, R. K. (1998). The New Threat of Mass Destruction. Foreign Affairs, 77(1), 26-41.

Betts, R. K. (2002). The Soft Underbelly of American Primacy: Tactical Advantages of Terror. Political Science Quarterly., 117(1 ), 19-36.

Bienenstock, E. J., \& Sageman, M. (2005). Operationalizing Terror In The Name Of God: Using Two-Mode Networks To Link Terrorism To Islamic Institutions, International Sunbelt Social Network Conference. Redondo Beach, CA.

Borgatti, S. P., Everett, M. G., \& Freeman, L. C. (2002). UCINET 6 for Windows: Software for social network analysis (Version 6.102). Harvard, Massachusetts: Analytic Technologies.

Bouty, I. (2000). Interpersonal and Interaction Influences on Informal Resource Exchanges between R\&D Researchers across Organizational Boundaries. The Academy of Management Journal, 43(1), 50-65.

Boyns, D., \& Ballard, J. D. (2004). Developing a Sociological Theory for the Empirical Understanding of Terrorism. American Sociologist, 35(2), 5-25.

Burt, R. S. (2005). Brokerage and closure: An introduction to social capital. Oxford: Oxford University Press.

Correlates of War II. (2004, March 26, 2004). National Material Capabilities (v3.01). Retrieved November 20 2004, 2004, from http://cow2.la.psu.edu/

Crenshaw, M. (2001). Why America? The Globalization of Civil War. Current History, 100, 425-432. 
Crenshaw, M., Dugan, L., \& LaFree, G. (2006). In Why the United States is Targeted by Terrorism. Paper presented at the International Studies Association Annual Convention, , San Diego, California.

Cronin, A. K. (2003). Behind the Curve: Globalization and International Terrorism. International Security, 27(3), 30-58.

DiMaggio, P. J., \& Powell, W. W. (1983). The iron cage revisited: Institutional isomorphism and collective rationality in organizational fields. American sociological review, 48, 147-160.

Doran, M. S. (2002). Somebody Else's Civil War. Foreign Affairs, 81(1), 22-42.

Eland, I. (1998). Does U.S. Intervention Overseas Breed Terrorism? The Historical Record (No. 50). Washington D.C. : Cato Institute.

Erickson, B. H. (1981). Secret Societies and Social Structure. Social forces, 60(1), 188-210.

Eubank, W., \& Weinberg, L. (2001). Terrorism and Democracy: Perpetrators and Victims. Terrorism \& Political Violence, 13(1), 155-164.

Feenstra, R. C. (1996). U.S. Imports, 1972-1994: Data and Concordances (No. 5515). Cambridge, Massachusetts: National Bureau of Economic Research.

Feenstra, R. C. (1997). U.S. Exports, 1972-1994, With State Exports and Other U.S. Data (No. 5990). Cambridge, Massachusetts: National Bureau of Economic Research.

Feenstra, R. C. (2004a). US Exports: National Bureau of Economic Research (NBER).

Feenstra, R. C. (2004b). US Imports: National Bureau of Economic Research (NBER).

Fishel, K. L. (2002). Challenging the Hegemon: Al Qaeda's Elevation of Asymmetric Insurgent Warfare Onto the Global Arena. Low Intensity Conflict \& Law Enforcement, 11(2 - 3), 285-298.

Gleditsch, N. P., Wallensteen, P., Eriksson, M., Sollenberg, M., \& Strand, H. (2002). Armed Conflict 1946-2001: A New Dataset. Journal of Peace Research, 39(5), 615-637. 
Glynn, S. (2005). Deconstructing Terrorism. Philosophical Forum, 36(1), 113-128.

Harbom, L., Högbladh, S., \& Wallensteen, P. (2006). Armed Conflict and Peace Agreements. Journal of Peace Research, 43(5), 617-631.

Heston, A., Summers, R., \& Aten, B. (2006). Penn World Tables 6.2: Center for International Comparisons of Production, Income and Prices at the University of Pennsylvania.

Hoffmann, S. (2002). Clash of Globalizations. Foreign Affairs, 81(4), 104-115.

International Monetary Fund. (2007). World Economic Outlook Database: International Monetary Fund,.

Jervis, R. (2003). Understanding the Bush Doctrine. Political Science Quarterly, 118(3), 365388.

Johnson, C. (2002). American Militarism and Blowback: The Costs of Letting the Pentagon Dominate Foreign Policy. New Political Science, 24(1), 21-38.

Judge, C. S. (2002). Hegemony of the Heart. Policy Review, 1(110), 3-14.

Juergensmeyer, M. (2003). Terror in the Mind of God : The Global Rise of Religious Violence (Third ed.). Berkley: University of California Press.

Kane, T. (2005, October 27, 2004). Global U.S. Troop Deployment, 1950-2003. Retrieved March 10 2007, 2007, from http://www.heritage.org/Research/NationalSecurity/cda0411.cfm\#_ftnref1

Krebs, V. (2002). Uncloaking Terrorist Networks. First Monday, 7(4), [firstmonday.org/issues/issue7_4/krebs/index.html].

Laqueur, W. (2004). The Terrorism to Come. Policy Review(126), 49-64.

Lewis, B. (1998). Usama bin Laden's Declaration of Jihad. Foreign Affairs, 77(3), 14-19.

Li, Q., \& Schaub, D. (2004). Economic Globalization and Transnational Terrorism: A Pooled Time-Series Analysis. Journal of Conflict Resolution, 48(2), 230-258. 
Long, J. S. (1997). Regression Models for Categorical and Limited Dependent Variables. Thousand Oaks, California: Sage Publications.

Long, J. S., \& Freese, J. (2003). Regression Models for Categorical Dependent Variables Using Stata (Revised ed.). College Station, TX: Stata Press.

Marshall, M. G., \& Jaggers, K. (2003). POLITY IV. Retrieved September 1 2004, 2004, from http://www.cidcm.umd.edu/inscr/polity/

McCammon, H. J., Granberg, E. M., Campbell, K. E., \& Mowery, C. (2001). How Movements Win: Gendered Opportunity Structures And U.S. Women's Suffrage Movements, 1866 to 1919. American Sociological Review, 66(1), 49-70.

McCarthy, J. D., \& Zald, M. N. (1977). Resource Mobilization and Social Movements: A Partial Theory. American Journal of Sociology, 82(6), 1212-1241.

MIPT. (2006, Jan. 8, 2006 ). MIPT Terrorism Knowledge Base. Retrieved January 29, 2006, 2006, from http://www.tkb.org/Home.jsp

Mockaitis, T. R. (2003). Winning the Hearts and Minds in the 'War on Terrorism. In T. R. Mockaitis \& P. B. Rich (Eds.), Grand Strategy in the War Against Terrorism (pp. 21-38). London: Frank Cass.

Mousseau, M. (2002). Market Civilization and Its Clash with Terror. International Security, $27(3), 5-29$.

Pape, R. (2005). Dying to Win : The Strategic Logic of Suicide Terrorism. New York Random House

Pillar, P. R. (2001). Terrorism and U. S. Foreign Policy: Brookings Institution Press.

Putnam, R. D. (1993). Making democracy work: Civic traditions in modern Italy. Princeton, New Jersey: Princeton University Press. 
Putnam, R. D. (2000). Bowling alone: The collapse and revival of American community. New York, New York: Simon \& Schuster.

Reinares, F. (1998). Democratic Regimes, Internal Security Policy and the Threat of Terrorism. Australian Journal of Politics \& History, 44(3), 351.

Rogers, W. H. (1993). Regression standard errors in clustered samples. Stata technical bulletin, 13, 1923-1928.

Sageman, M. (2004). Understanding Terror Networks. Philadelphia: University of Pennsylvania Press.

Simon, S., \& Benjamin, D. (2001). The Terror. Survival, 43(4), 5-18.

Singer, J. D. (1988). Reconstructing the Correlates of War Dataset on Material Capabilities of States, 1816-1985. International Interactions, 14(2), 115-132.

Sobek, D., \& Braithwaite, A. (2005). Victim of Success: American Dominance and Terrorism. Conflict Management and Peace Science, 22(2), 135-148.

Stankiewicz, W. (2005). International Terrorism at Sea as a Menace to the Civilization of the 21st Century. American Behavioral Scientist, 48(6), 683-699.

Talhami, G. H. (2003). Muslims, Islamists, and the Cold War. Small Wars and Insurgencies, 14(1), 109-126.

Tushman, M. L., \& Scanlan, T. J. (1981). Boundary Spanning Individuals: Their Role in Information Transfer and Their Antecedents. The Academy of Management Journal, 24(2), 289-305.

Uppsala Conflict Data Program (UCDP), \& Research Institute - Oslo (PRIO). (2006). UCDP/PRIO Conflict Dataset Codebook. Oslo: Uppsala Conflict Data Program (UCDP) \& International Peace Research Institute, Oslo (PRIO).

Watson, J. L. (1997). Golden Arches East: McDonald's in East Asia: Stanford University Press. 
Wiktorowicz, Q., \& Kaltner, J. (2003). Killing in the Name of Islam: Al-Qaeda's Justification for September 11. Middle East Policy, 10(2), 76-92.

Zanini, M., \& Edwards, S. J. A. (2001). The Network of Terror in the Information Age. In J. Arquilla \& D. F. Ronfeldt (Eds.), Networks and Netwars: The Future of Terror, Crime, and Militancy. Santa Monica, California: The RAND Corporation.

Table 1: Size of Organizational Membership

\begin{tabular}{|l|l|l|}
\hline Size intervals & Code & $\mathbf{N}$ \\
\hline $\begin{array}{l}0-100 \text { \& low } \\
\text { confidence }\end{array}$ & 0 & $\begin{array}{l}261 \\
77: \text { low-confidence } \\
184: 0-100\end{array}$ \\
\hline $100-1000$ & 1 & 74 \\
\hline $1000-10,000$ & 2 & 45 \\
\hline 10,000 or more & 3 & 12 \\
\hline
\end{tabular}

Table 2: Selected Comparisons Organizations that Target or Attack US Interests

\begin{tabular}{|l|l|l|}
\hline & Targeted & Attacked \\
\hline Proportion less than 10 years old & $88 \%$ & $59 \%$ \\
\hline Islamically inspired & $72 \%$ & $41 \%$ \\
\hline Hosted in non-democratic states & $67 \%$ & $33 \%$ \\
\hline $\begin{array}{l}\text { Presence of 1,000 or more US } \\
\text { military members }\end{array}$ & $67 \%$ & $20 \%$ \\
\hline Fewer than 100 members & $65 \%$ & $57 \%$ \\
\hline
\end{tabular}


Table 3: Models of Targeting and Attacking US Interests

\begin{tabular}{|c|c|c|c|c|}
\hline & \multicolumn{2}{|c|}{ Targeting US Interests } & \multicolumn{2}{|c|}{ Attacking US Interests } \\
\hline & $\begin{array}{c}\text { Without } \\
\text { Democracy } \\
\text { \& US } \\
\text { Troops }\end{array}$ & $\begin{array}{c}\text { With } \\
\text { Democracy } \\
\text { \& US } \\
\text { Troops }\end{array}$ & $\begin{array}{c}\text { Without } \\
\text { Democracy } \\
\text { \& US } \\
\text { Troops }\end{array}$ & $\begin{array}{c}\text { With } \\
\text { Democracy } \\
\text { \& US } \\
\text { Troops }\end{array}$ \\
\hline Islamic ideology & $\begin{array}{l}0.944^{*} \\
(0.538)\end{array}$ & $\begin{array}{l}1.121^{*} \\
(0.624)\end{array}$ & $\begin{array}{l}0.683^{*} \\
(0.376) \\
\end{array}$ & $\begin{array}{c}0.586 \\
(0.427) \\
\end{array}$ \\
\hline Max 2000 US troops (dichotomous) & $\begin{array}{c}2.504 * * * \\
(0.627) \\
\end{array}$ & $\begin{array}{l}-0.958 \\
(1.082) \\
\end{array}$ & $\begin{array}{c}0.019 \\
(0.451) \\
\end{array}$ & $\begin{array}{l}-1.471 \\
(0.921) \\
\end{array}$ \\
\hline Democracy & $\begin{array}{l}-0.068 \\
(0.664) \\
\end{array}$ & $\begin{array}{c}0.608 \\
(1.067) \\
\end{array}$ & $\begin{array}{l}-0.777 \\
(0.477) \\
\end{array}$ & $\begin{array}{l}-0.641 \\
(0.478) \\
\end{array}$ \\
\hline US troops/Non-democratic state & & $\begin{array}{c}5.989 * * * \\
(1.530) \\
\end{array}$ & & $\begin{array}{l}3.048 * * \\
(1.221) \\
\end{array}$ \\
\hline Log exports (UN) & $\begin{array}{c}-0.308 * * \\
(0.133)\end{array}$ & $\begin{array}{c}-0.423 * * * \\
(0.112)\end{array}$ & $\begin{array}{c}-0.244 * * \\
(0.121) \\
\end{array}$ & $\begin{array}{c}-0.270 * * \\
(0.130) \\
\end{array}$ \\
\hline McDonalds (dichotomous) & $\begin{array}{l}-0.967 \\
(0.632) \\
\end{array}$ & $\begin{array}{l}-0.058 \\
(0.766) \\
\end{array}$ & $\begin{array}{l}1.274 * * \\
(0.606)\end{array}$ & $\begin{array}{c}2.057 * * * \\
(0.695) \\
\end{array}$ \\
\hline Organizational membership & $\begin{array}{l}-0.090 \\
(0.345) \\
\end{array}$ & $\begin{array}{c}0.182 \\
(0.423) \\
\end{array}$ & $\begin{array}{l}-0.020 \\
(0.228) \\
\end{array}$ & $\begin{array}{l}-0.006 \\
(0.241)\end{array}$ \\
\hline Alliance connections & $\begin{array}{c}0.145^{* *} \\
(0.068)\end{array}$ & $\begin{array}{l}0.132^{*} \\
(0.077)\end{array}$ & $\begin{array}{l}0.186^{* * *} \\
(0.075)\end{array}$ & $\begin{array}{c}0.190 * * \\
(0.080) \\
\end{array}$ \\
\hline State sponsorship (dichotmous) & $\begin{array}{l}-0.943^{*} \\
(0.547)\end{array}$ & $\begin{array}{l}-0.900 \\
(0.600)\end{array}$ & $\begin{array}{l}-0.344 \\
(0.505)\end{array}$ & $\begin{array}{l}-0.235 \\
(0.524)\end{array}$ \\
\hline Three or fewer attacks & $\begin{array}{l}-0.229 \\
(0.542)\end{array}$ & $\begin{array}{l}-0.387 \\
(0.658)\end{array}$ & $\begin{array}{c}-1.32 * * * \\
(0.322)\end{array}$ & $\begin{array}{c}-1.46^{* * * *} \\
(0.336)\end{array}$ \\
\hline Military expenditures per capita & $\begin{array}{c}0.001 \\
(0.002)\end{array}$ & $\begin{array}{c}-0.004 * * \\
(0.002)\end{array}$ & $\begin{array}{c}0.001 \\
(0.001)\end{array}$ & $\begin{array}{l}-0.000 \\
(0.001)\end{array}$ \\
\hline GDP per capita & $\begin{array}{l}-0.00005 \\
(0.00009)\end{array}$ & $\begin{array}{c}0.00019 * * \\
(0.00007)\end{array}$ & $\begin{array}{l}-0.00002 \\
(0.00006)\end{array}$ & $\begin{array}{c}0.00004 \\
(0.00005)\end{array}$ \\
\hline Years of internal/external civil war & $\begin{array}{c}-0.35 * * * \\
(0.087)\end{array}$ & $\begin{array}{c}-0.463 * * * \\
(0.114)\end{array}$ & $\begin{array}{l}-0.092 \\
(0.064)\end{array}$ & $\begin{array}{l}-0.050 \\
(0.067)\end{array}$ \\
\hline Constant & $\begin{array}{l}5.288^{*} \\
(3.120)\end{array}$ & $\begin{array}{c}5.795 * * \\
(2.587) \\
\end{array}$ & $\begin{array}{l}4.313^{*} \\
(2.587)\end{array}$ & $\begin{array}{c}3.833 \\
(2.802)\end{array}$ \\
\hline $\mathbf{N}$ & 387 & 387 & 387 & 387 \\
\hline Log-likelihood & -83.355 & -74.894 & -148.865 & -144.178 \\
\hline chi2 (Wald) & 232.445 & 604.187 & 56.518 & 70.394 \\
\hline Pseudo $\mathrm{R}^{2}$ (McFadden) & 0.383 & 0.445 & 0.158 & 0.184 \\
\hline AIC & 192.711 & 177.788 & 323.730 & 316.357 \\
\hline BIC & 244.170 & 233.206 & 375.189 & 371.775 \\
\hline
\end{tabular}

$* \mathrm{p}<0.10 ; * * \mathrm{p}<0.05 ; * * * \mathrm{p}<0.01$ 
Table 4: Simulated Change in Probability

\begin{tabular}{|c|c|c|c|c|}
\hline & \multicolumn{2}{|c|}{ Targeting US Interests } & \multicolumn{2}{|c|}{ Attacking US Interests } \\
\hline & $\begin{array}{c}\text { Without } \\
\text { Democracy } \\
\text { \& US } \\
\text { Troops }\end{array}$ & $\begin{array}{c}\text { With } \\
\text { Democracy } \\
\text { \& US } \\
\text { Troops }\end{array}$ & $\begin{array}{c}\text { Without } \\
\text { Democracy } \\
\text { \& US } \\
\text { Troops }\end{array}$ & $\begin{array}{c}\text { With } \\
\text { Democracy } \\
\text { \& US } \\
\text { Troops }\end{array}$ \\
\hline Probability at the means & 0.0351 & 0.0191 & 0.1370 & 0.1267 \\
\hline \multicolumn{5}{|l|}{ Islamic ideology } \\
\hline Yes & 0.0671 & 0.0419 & 0.2062 & NS \\
\hline No & 0.0272 & 0.0141 & 0.1160 & NS \\
\hline \multicolumn{5}{|l|}{ Max 2000 US troops (dichotomous) } \\
\hline Yes & 0.1950 & NS & NS & NS \\
\hline No & 0.0194 & NS & NS & NS \\
\hline \multicolumn{5}{|l|}{ US troops/Non-democratic state } \\
\hline Yes & N/A & 0.8096 & N/A & 0.6921 \\
\hline No & N/A & 0.0105 & N/A & 0.0964 \\
\hline \multicolumn{5}{|l|}{ Log exports (UN) } \\
\hline+1 std. deviation & 0.0198 & 0.0086 & 0.0905 & 0.0796 \\
\hline-1 std. deviation & 0.0591 & 0.0395 & 0.1963 & 0.1896 \\
\hline \multicolumn{5}{|l|}{ McDonalds (dichotomous) } \\
\hline Yes & NS & NS & 0.1698 & 0.1793 \\
\hline No & NS & NS & 0.0541 & 0.0272 \\
\hline \multicolumn{5}{|l|}{ Alliance connections } \\
\hline No connections & 0.0288 & 0.0159 & 0.1089 & 0.0999 \\
\hline+1 std. deviation & 0.0498 & 0.0265 & 0.2022 & 0.1897 \\
\hline+2 std. deviation & 0.0705 & 0.0367 & 0.2888 & 0.2752 \\
\hline \multicolumn{5}{|l|}{ Three or fewer attacks } \\
\hline Yes & NS & NS & 0.1018 & 0.0908 \\
\hline No & NS & NS & 0.2975 & 0.3003 \\
\hline \multicolumn{5}{|l|}{ Years of internal/external civil war } \\
\hline No years & 0.0869 & 0.0656 & NS & NS \\
\hline+1 std. deviation & 0.0108 & 0.0039 & NS & NS \\
\hline
\end{tabular}

${ }^{1}$ This definition would include, for instance, an attack on a foreign-owned McDonalds but exclude attacks on US military personnel or US military installations.

${ }^{2}$ Until March 30, 2008, MIPT's Terrorism Knowledge Base was available online. The references throughout this paper include the URL to the legacy site. Subsequently, MIPT closed the site and transferred the data to the University of Maryland's National Consortium for the Study of Terrorism and Responses to Terrorism (START) - see www.start.umd.edu. 
${ }^{3}$ For a further explication of this document see (Wiktorowicz \& Kaltner, 2003).

${ }^{4}$ Others make similar arguments both generally (Addison \& Murshed, 2005, 69) (Betts, 1998, 28) or within the context of the radical Islamic struggle against the United States.

${ }^{5} \mathrm{~A}$ replication dataset is available from $<$ URL to be included $>$ ).

${ }^{6}$ The IMF does not have data for Afghanistan and Iraq. To fill this gap, we searched the web for 1997 estimates, finding several. The consensus estimate (in purchasing power parity terms) was $\$ 800$ for Afghanistan and $\$ 2,000$ for Iraq. These estimates seemed reasonable, as the countries with similar GDP/capita values were in line with our subjective expectations.

${ }^{7}$ We are indebted to an anonymous reviewer who suggested we should test the results against a dataset without Iraqi and Afghani organizations. 


\section{Appendix}

Table A.1 Descriptive Statistics

\begin{tabular}{|c|c|c|c|c|c|c|}
\hline & $\mathbf{N}$ & Mean & Std. Dev & Min & Max & $\begin{array}{c}\text { Categorical: } \\
\text { Cases }=1\end{array}$ \\
\hline Attacking the US & 387 & 0.111 & 0.315 & 0 & 1 & 43 \\
\hline Targeting the US & 387 & 0.171 & 0.377 & 0 & 1 & 66 \\
\hline Islamic ideology & 387 & 0.279 & 0.449 & 0 & 1 & 108 \\
\hline US troops (dichotomous) & 387 & 0.264 & 0.441 & 0 & 1 & 102 \\
\hline Democracy & 387 & 0.721 & 0.449 & 0 & 1 & 279 \\
\hline US troops/Non-democratic state & 387 & 0.121 & 0.327 & 0 & 1 & 47 \\
\hline Log exports (UN) & 387 & 23.750 & 1.787 & 16.376 & 27.032 & \\
\hline McDonalds (dichotomous) & 387 & 0.801 & 0.400 & 0 & 1 & 310 \\
\hline Organizational membership & 387 & 0.517 & 0.809 & 0 & 3 & N/A \\
\hline Alliance connections & 387 & 1.411 & 2.563 & 0 & 33 & N/A \\
\hline State sponsorship (dichotmous) & 387 & 0.083 & 0.276 & 0 & 1 & 32 \\
\hline Three or fewer attacks & 387 & 0.744 & 0.437 & 0 & 1 & 288 \\
\hline $\begin{array}{r}\text { Military expenditures per } \\
\text { capita }\end{array}$ & 387 & 327.435 & 446.126 & 1.859 & 1939.856 & N/A \\
\hline GDP per capita & 387 & 10057.480 & 8431.954 & 478.708 & 26999.630 & N/A \\
\hline $\begin{array}{r}\text { Years of internal/external civil } \\
\text { war }\end{array}$ & 387 & 2.770 & 3.478 & 0 & 8 & N/A \\
\hline
\end{tabular}


Table A.2: Organizations That Targeted US Interests, 1998-2005

(Bold indicates a group that also attacked US interests.)

\begin{tabular}{|c|c|}
\hline Organization & $\begin{array}{l}\text { Host } \\
\text { country }\end{array}$ \\
\hline 1920 Revolution Brigades & Iraq \\
\hline Aden Abyan Islamic Army (AAIA) & Yemen \\
\hline Ali Bin Abu Talib Jihad Organization & Iraq \\
\hline Anarchist Struggle & Greece \\
\hline Anarchists' Attack Group & Greece \\
\hline Ansar al-Islam & Iraq \\
\hline Ansar al-Jihad & Iraq \\
\hline Ansar al-Sunnah Army & Iraq \\
\hline Black Star & Greece \\
\hline Brigades of Imam al-Hassan al-Basri & Iraq \\
\hline Brigades of Martyr Ahmed Yassin & Iraq \\
\hline Brigades of the Victorious Lion of God & Iraq \\
\hline Chukakuha & Japan \\
\hline Divine Wrath Brigades & Iraq \\
\hline Freedom for Mumia Abu-Jamal & Switzerland \\
\hline Friendship Society & Greece \\
\hline Iraqi Revenge Brigades & Iraq \\
\hline Islamic Army in Iraq & Iraq \\
\hline Islamic Jihad Brigades & Iraq \\
\hline Jaish al-Taifa al-Mansoura & Iraq \\
\hline Jaish-ul-Muslimin & Afghanistan \\
\hline Jamatul Mujahedin Bangladesh & Bangladesh \\
\hline Jund al-Sham & Afghanistan \\
\hline Karbala Brigades & Iraq \\
\hline Lashkar-I-Omar & Pakistan \\
\hline Lashkar-e-Taiba (LeT) & Pakistan \\
\hline Mahdi Army & Iraq \\
\hline Mariano Moreno National Liberation Commando & Venezuela \\
\hline Mujahideen Message & Afghanistan \\
\hline Mujahideen Shura Council & Iraq \\
\hline Muslims Against Global Oppression (MAGO) & South Africa \\
\hline Revolutionary Army & Japan \\
\hline Revolutionary Nuclei & Greece \\
\hline Saif-ul-Muslimeen & Afghanistan \\
\hline Saraya al-Shuhuada al-jihadiyah fi al-Iraq & Iraq \\
\hline Shurafa al-Urdun & Jordan \\
\hline Taliban & Afghanistan \\
\hline Tawhid and Jihad & Iraq \\
\hline al-Ahwal Brigades & Iraq \\
\hline al-Faruq Brigades & Iraq \\
\hline al-Qaeda & Pakistan \\
\hline al-Qaeda Organization in the Land of the Two Rivers & Iraq \\
\hline al-Qaeda in the Arabian Penninsula (AQAP) & Saudi Arabia \\
\hline
\end{tabular}

Table A.3: Organizations That Attacked US Interests, 1998-2005

(Bold indicates a group that also targeted US interests.) 


\begin{tabular}{|c|c|}
\hline Organization & Host country \\
\hline 1920 Revolution Brigades & Iraq \\
\hline Abu Sayyaf Group (ASG) & Philippines \\
\hline Aden Abyan Islamic Army (AAIA) & Yemen \\
\hline Anarchist Struggle & Greece \\
\hline Anarchists' Attack Group & Greece \\
\hline Animal Liberation Front (ALF) & United States of America \\
\hline Ansar al-Sunnah Army & Iraq \\
\hline Anti-Authority Erotic Cells & Greece \\
\hline Anti-Power Struggle & Greece \\
\hline Asbat al-Ansar & Lebanon \\
\hline Baloch Liberation Army (BLA) & Pakistan \\
\hline Battalion of the Martyr Abdullah Azzam & Egypt \\
\hline Black Panthers (West Bank/Gaza) & Israel \\
\hline Black Star & Greece \\
\hline Breton Revolutionary Army (ARB) & France \\
\hline Brigades of Martyr Ahmed Yassin & Iraq \\
\hline Coalition to Save the Preserves (CSP) & United States of America \\
\hline Communist Party of Nepal-Maoists (CPN-M) & Nepal \\
\hline DHKP-C & Turkey \\
\hline Divine Wrath Brigades & Iraq \\
\hline Earth Liberation Front (ELF) & United States of America \\
\hline Eritrean Islamic Jihad Movement (EIJM) & Eritrea \\
\hline Free Aceh Movement (GAM) & Indonesia \\
\hline Free People of Galillee & Israel \\
\hline Freedom for Mumia Abu-Jamal & Switzerland \\
\hline Friendship Society & Greece \\
\hline Group of Popular Combatants (GPC) & Ecuador \\
\hline Hamas & Israel \\
\hline Harakat ul-Mudjahidin (HuM) & Pakistan \\
\hline Islamic Army in Iraq & Iraq \\
\hline Islamic Glory Brigades in the Land of the Nile & Egypt \\
\hline Jaish al-Taifa al-Mansoura & Iraq \\
\hline Jaish-e-Mohammad (JeM) & Pakistan \\
\hline Jemaah Islamiya $(\mathrm{JI})$ & Indonesia \\
\hline Lashkar-I-Omar & Pakistan \\
\hline Liberation Tigers of Tamil Eelam (LTTE) & Sri Lanka \\
\hline Mariano Moreno National Liberation Commando & Venezuela \\
\hline Moro Islamic Liberation Front (MILF) & Philippines \\
\hline Movsar Baryayev Gang & Russia \\
\hline Muslim United Army & Pakistan \\
\hline Muslims Against Global Oppression (MAGO) & South Africa \\
\hline National Liberation Army (Colombia) & Colombia \\
\hline New People's Army (NPA) & Philippines \\
\hline New Revolutionary Popular Struggle (NELA) & Greece \\
\hline Palestinian Islamic Jihad (PIJ) & Israel \\
\hline People's Revolutionary Militias & Ecuador \\
\hline Organization & Host country \\
\hline
\end{tabular}




\begin{tabular}{|l|l|}
\hline Popular Liberation Army & Colombia \\
\hline Popular Revolutionary Action & Greece \\
\hline Proletarian Resistance & Greece \\
\hline Red Line & Greece \\
\hline Revolutionary Armed Forces of Colombia (FARC) & Colombia \\
\hline Revolutionary Army & Japan \\
\hline Revolutionary Cells Animal Liberation Brigade & United States of America \\
\hline Revolutionary Nuclei & Greece \\
\hline Revolutionary Organization 17 November (RO-N17) & Greece \\
\hline Revolutionary Struggle & Greece \\
\hline Revolutionary Subversive Faction-Commando Unibomber & Greece \\
\hline Rigas Fereos & Greece \\
\hline Saraya al-Shuhuada al-jihadiyah fi al-Iraq & Iraq \\
\hline Shining Path & Peru \\
\hline Shurafa al-Urdun & Jordan \\
\hline Solidarity for Political Prisoners & Greece \\
\hline TKP/ML-TIKKO & Turkey \\
\hline Taliban & Afghanistan \\
\hline Tawhid and Jihad & Iraq \\
\hline United Self-Defense Forces of Colombia (AUC) & Colombia \\
\hline al-Fatah & Israel \\
\hline al-Qaeda & Pakistan \\
\hline al-Qaeda Organization in the Land of the Two Rivers & Iraq \\
\hline al-Qaeda in the Arabian Penninsula (AQAP) & Saudi Arabia \\
\hline
\end{tabular}


Table A.4: Compact Summary of Findings Across Alternative Specifications of Troop Level and Economic Embedding Variables

\begin{tabular}{|c|c|c|}
\hline & Targeting - 80 models & Attacking - 80 models \\
\hline Islamic ideology & $\begin{array}{l}\text { Complete agreement on sign (positive) } \\
\text { Nearly complete agreement on significance }\end{array}$ & $\begin{array}{l}\text { Agreement on sign in UN data } \\
\text { Not significant in most specifications }\end{array}$ \\
\hline US troops (dichotomous) & Complete agreement on sign (positive) and significance level & Poor agreement on sign and significance \\
\hline Democracy & $\begin{array}{l}\text { Complete agreement on sign and significance level } \\
\text { No effect }\end{array}$ & $\begin{array}{l}\text { Near agreement on sign } \\
\text { Significance varies greatly }\end{array}$ \\
\hline $\begin{array}{r}\text { US troops/Non-democratic } \\
\text { state }\end{array}$ & Complete agreement on sign (positive) and significance level & Complete agreement on sign and significance level \\
\hline Trade variables & $\begin{array}{l}\text { Near complete agreement on sign (negative) and significance } \\
\text { for UN data } \\
\text { Not significant in most other specifications }\end{array}$ & $\begin{array}{l}\text { Near complete agreement on sign and significance for UN } \\
\text { data } \\
\text { Not significant in most other specifications }\end{array}$ \\
\hline McDonalds (dichotomous) & $\begin{array}{l}\text { Complete agreement on sign (negative) } \\
\text { Significance varies }\end{array}$ & $\begin{array}{l}\text { Complete agreement on sign } \\
\text { Nearly complete agreement on significance }\end{array}$ \\
\hline Organizational membership & Complete agreement - no effect & Complete agreement - no effect \\
\hline Alliance connections & $\begin{array}{l}\text { Complete agreement on sign (positive) } \\
\text { Nearly complete agreement on significance }\end{array}$ & $\begin{array}{l}\text { Complete agreement on sign (positive) and significance } \\
\text { level }\end{array}$ \\
\hline $\begin{array}{r}\text { State sponsorship } \\
\text { (dichotmous) }\end{array}$ & $\begin{array}{l}\text { Complete agreement on sign (negative) } \\
\text { Nearly complete agreement on significance } \\
\text { Almost all no effect }\end{array}$ & $\begin{array}{l}\text { Complete agreement on sign (negative) } \\
\text { Complete agree on significance }- \text { no effect }\end{array}$ \\
\hline Three or fewer attacks & Complete agreement - no effect & $\begin{array}{l}\text { Complete agreement on sign (negative) and significance } \\
\text { level }\end{array}$ \\
\hline $\begin{array}{r}\text { Military expenditures per } \\
\text { capita }\end{array}$ & $\begin{array}{l}\text { Nearly complete agreement on sign (negative) } \\
\text { Nearly complete agreement on significance }\end{array}$ & $\begin{array}{l}\text { Complete agreement on sign } \\
\text { Almost all no effect }\end{array}$ \\
\hline GDP per capita & $\begin{array}{l}\text { Complete agreement on sign (positive) } \\
\text { Significance varies greatly }\end{array}$ & $\begin{array}{l}\text { Complete agreement on sign } \\
\text { Almost all no effect }\end{array}$ \\
\hline $\begin{array}{r}\text { Years of Internal/external } \\
\text { civil war }\end{array}$ & Complete agreement and sign significance level & $\begin{array}{l}\text { Complete agreement on sign } \\
\text { Significance varies greatly }\end{array}$ \\
\hline
\end{tabular}


Table A.5: Summary of Alternative Specifications of US Troop Cutoff and Definition - Targeting the United States

\begin{tabular}{|c|c|c|c|c|c|c|c|c|c|c|c|c|c|c|c|c|}
\hline $\begin{array}{l}\text { Targeting the United States: Exports } \\
\text { to the World }\end{array}$ & & & & & & & & & & & & & & & & \\
\hline Troop variable type & $\operatorname{Max}$ & Max & $\operatorname{Max}$ & Max & Max & Max & $\operatorname{Max}$ & Max & Avg & Avg & Avg & Avg & Avg & Avg & Avg & Avg \\
\hline Interaction? & No & Yes & No & Yes & No & Yes & No & Yes & No & Yes & No & Yes & No & Yes & No & Yes \\
\hline Islamic ideology & ++ & & + & & + & + & + & + & ++ & & + & + & + & + & + & + \\
\hline US troops/Non-democratic state & N/A & ++ & N/A & ++ & N/A & ++ & N/A & ++ & N/A & ++ & N/A & ++ & N/A & ++ & N/A & ++ \\
\hline Log exports to the world (UN) & & -- & & -- & -- & -- & -- & -- & & -- & - & -- & -- & -- & -- & -- \\
\hline McDonalds (dichotomous) & -- & -- & -- & - & & & & & -- & - & & & & & & \\
\hline Organizational membership & & & & & & & & & & & & & & & & \\
\hline Alliance connections & ++ & ++ & ++ & + & ++ & + & ++ & + & ++ & + & ++ & + & ++ & + & + & + \\
\hline GDP per capita & & & & & & ++ & & ++ & & & & ++ & & ++ & & \\
\hline Years of Internal/external civil war & -- & -- & -- & -- & -- & -- & -- & -- & -- & -- & -- & -- & -- & -- & -- & -- \\
\hline
\end{tabular}

Key: - = negative sign, $10 \%$ significance; -- = negative sign, $5 \%$ significance; + = positive sign, $10 \%$ significance; ++ = positive sign, $5 \%$ significance. 
Table A.6: Summary of Alternative Specifications of US Troop Cutoff and Definition - Targeting the United States (continued)

\begin{tabular}{|c|c|c|c|c|c|c|c|c|c|c|c|c|c|c|c|c|}
\hline \multicolumn{17}{|l|}{$\begin{array}{l}\text { Targeting the United States: Imports } \\
\text { from the World } \\
\end{array}$} \\
\hline Troop variable type & Max & Max & Max & Max & Max & Max & Max & Max & Avg & Avg & Avg & Avg & Avg & Avg & Avg & Avg \\
\hline Interaction? & No & Yes & No & Yes & No & Yes & No & Yes & No & Yes & No & Yes & No & Yes & No & Yes \\
\hline Islamic ideology & ++ & + & + & & + & + & + & + & ++ & & + & + & + & + & ++ & ++ \\
\hline \multicolumn{17}{|l|}{ Democracy } \\
\hline US troops/Non-democratic state & N/A & ++ & N/A & ++ & N/A & ++ & N/A & ++ & N/A & ++ & N/A & ++ & N/A & ++ & N/A & ++ \\
\hline Log imports from the world (UN) & & -- & & -- & -- & -- & -- & -- & & -- & -- & -- & -- & -- & -- & -- \\
\hline McDonalds (dichotomous) & -- & -- & -- & & & & & & - & & & & & & & \\
\hline \multicolumn{17}{|l|}{ Organizational membership } \\
\hline GDP per capita & & ++ & & ++ & & ++ & & ++ & & + & & ++ & & ++ & & ++ \\
\hline Years of Internal/external civil war & -- & -- & -- & -- & -- & -- & -- & -- & -- & -- & -- & -- & -- & -- & -- & -- \\
\hline & & & & & & & & & & & & & & & & \\
\hline
\end{tabular}

Key: - = negative sign, $10 \%$ significance; -- = negative sign, $5 \%$ significance; $+=$ positive sign, $10 \%$ significance; $++=$ positive sign, $5 \%$ significance . 
Table A.7: Summary of Alternative Specifications of US Troop Cutoff and Definition - Targeting the United States (continued)

\begin{tabular}{|c|c|c|c|c|c|c|c|c|c|c|c|c|c|c|c|c|}
\hline \multirow{2}{*}{$\begin{array}{l}\text { Targeting the United States: Penn } \\
\text { World Table - OPENC trade } \\
\text { variable }\end{array}$} & & & & & & & & & & & & & & & & \\
\hline & & & & & & & & & & & & & & & & \\
\hline Troop variable type & Max & Max & Max & Max & Max & Max & Max & Max & Avg & Avg & Avg & Avg & Avg & Avg & Avg & Avg \\
\hline Cutoff & 100 & 100 & 1000 & 1000 & 2000 & 2000 & 5000 & 5000 & 100 & 100 & 1000 & 1000 & 2000 & 2000 & 5000 & 5000 \\
\hline Interaction? & No & Yes & No & Yes & No & Yes & No & Yes & No & Yes & No & Yes & No & Yes & No & Yes \\
\hline Islamic ideology & ++ & & + & & ++ & + & & & ++ & & + & + & + & + & + & + \\
\hline US troops (dichotomous) & ++ & & ++ & & ++ & & ++ & & ++ & & ++ & & ++ & & ++ & \\
\hline Democracy & & & & & & & & & & & & & & & & \\
\hline US troops/Non-democratic state & N/A & ++ & $\mathbf{N} / \mathbf{A}$ & ++ & N/A & ++ & $\mathbf{N} / \mathbf{A}$ & ++ & $\mathbf{N} / \mathbf{A}$ & ++ & $\mathbf{N} / \mathbf{A}$ & ++ & N/A & ++ & N/A & ++ \\
\hline Log OPENC & & & & & & & & & & & & & & & & \\
\hline McDonalds (dichotomous) & -- & -- & -- & -- & -- & & - & & -- & -- & -- & & -- & & & \\
\hline Organizational membership & & & & & & & & & & & & & & & & \\
\hline Alliance connections & ++ & ++ & ++ & ++ & ++ & + & ++ & + & ++ & + & ++ & ++ & ++ & + & ++ & + \\
\hline State sponsorship (dichotmous) & & & & & & & & & & & & & & & & \\
\hline Three or fewer attacks & & & & & & & & & & & & & & & & \\
\hline Military expenditures per capita & & & & & & - & & & & & & - & & - & & \\
\hline GDP per capita & & & & & & & & & & & & & & & & \\
\hline Years of Internal/external civil war & -- & -- & -- & -- & -- & -- & -- & -- & -- & -- & -- & -- & -- & -- & -- & -- \\
\hline
\end{tabular}

Key: - = negative sign, $10 \%$ significance; -- = negative sign, $5 \%$ significance $++=$ positive sign, $10 \%$ significance; $++=$ positive sign, $5 \%$ significance. 
Table A.8: Summary of Alternative Specifications of US Troop Cutoff and Definition - Targeting the United States (continued)

\begin{tabular}{|c|c|c|c|c|c|c|c|c|c|c|c|c|c|c|c|c|}
\hline \multicolumn{17}{|l|}{$\begin{array}{l}\text { Targeting the United States: Exports } \\
\text { to the US }\end{array}$} \\
\hline Troop variable type & Max & Max & Max & Max & $\operatorname{Max}$ & Max & Max & Max & Avg & Avg & Avg & Avg & Avg & Avg & Avg & Avg \\
\hline Interaction? & No & Yes & No & Yes & No & Yes & No & Yes & No & Yes & No & Yes & No & Yes & No & Yes \\
\hline Islamic ideology & ++ & & + & & + & + & & + & ++ & & + & + & + & + & + & + \\
\hline \multicolumn{17}{|l|}{ Democracy } \\
\hline US troops/Non-democratic state & N/A & ++ & N/A & ++ & N/A & ++ & N/A & ++ & N/A & ++ & N/A & ++ & N/A & ++ & N/A & ++ \\
\hline \multicolumn{17}{|l|}{ Log exports to US } \\
\hline McDonalds (dichotomous) & -- & -- & -- & -- & & & & & -- & -- & & & & & & \\
\hline \multicolumn{17}{|l|}{ Organizational membership } \\
\hline Alliance connections & ++ & + & ++ & + & ++ & + & ++ & + & ++ & + & ++ & + & ++ & + & ++ & + \\
\hline GDP per capita & & & & & & + & & & & & & + & & + & & \\
\hline Years of Internal/external civil war & -- & -- & -- & -- & -- & -- & -- & -- & - & -- & -- & -- & -- & -- & -- & -- \\
\hline
\end{tabular}

Key: - = negative sign, $10 \%$ significance; $--=$ negative sign, $5 \%$ significance; $+=$ positive sign, $10 \%$ significance; $++=$ positive sign, $5 \%$ significance. 
Table A.9: Summary of Alternative Specifications of US Troop Cutoff and Definition - Targeting the United States (continued)

\begin{tabular}{|c|c|c|c|c|c|c|c|c|c|c|c|c|c|c|c|c|}
\hline \multicolumn{17}{|l|}{$\begin{array}{l}\text { Targeting the United States: Imports } \\
\text { from the US }\end{array}$} \\
\hline Troop variable type & $\operatorname{Max}$ & Max & Max & Max & $\operatorname{Max}$ & Max & Max & Max & Avg & Avg & Avg & Avg & Avg & Avg & Avg & Avg \\
\hline Interaction? & No & Yes & No & Yes & No & Yes & No & Yes & No & Yes & No & Yes & No & Yes & No & Yes \\
\hline Islamic ideology & ++ & & + & & + & + & & + & + & & + & + & + & + & + & + \\
\hline \multicolumn{17}{|l|}{ Democracy } \\
\hline US troops/Non-democratic state & N/A & ++ & N/A & ++ & N/A & ++ & N/A & ++ & N/A & ++ & N/A & ++ & N/A & ++ & N/A & ++ \\
\hline \multicolumn{17}{|l|}{ Log imports from US } \\
\hline McDonalds (dichotomous) & -- & -- & -- & - & - & & & & -- & - & - & & - & & & \\
\hline \multicolumn{17}{|l|}{ Organizational membership } \\
\hline Alliance connections & ++ & + & ++ & + & ++ & + & ++ & + & ++ & + & ++ & + & ++ & + & ++ & + \\
\hline GDP per capita & & & & & & + & & & & & & + & & + & & \\
\hline Years of Internal/external civil war & -- & - & -- & - & -- & -- & -- & -- & - & - & -- & -- & -- & - & -- & -- \\
\hline
\end{tabular}

Key: - = negative sign, $10 \%$ significance; $--=$ negative sign, $5 \%$ significance; $+=$ positive sign, $10 \%$ significance; $++=$ positive sign, $5 \%$ significance. 
Table A.10: Summary of Alternative Specifications of US Troop Cutoff and Definition - Attacking the United States

\begin{tabular}{|c|c|c|c|c|c|c|c|c|c|c|c|c|c|c|c|c|}
\hline $\begin{array}{l}\text { Attacking the United States: Exports to } \\
\text { the World }\end{array}$ & & & & & & & & & & & & & & & & \\
\hline Troop variable type & Max & Max & Max & Max & Max & Max & Max & Max & Avg & Avg & Avg & Avg & Avg & Avg & Avg & Avg \\
\hline Cutoff & 100 & 100 & 1000 & 1000 & 2000 & 2000 & 5000 & 5000 & 100 & 100 & 1000 & 1000 & 2000 & 2000 & 5000 & 5000 \\
\hline Interactions? & No & Yes & No & Yes & No & Yes & No & Yes & No & Yes & No & Yes & No & Yes & No & Yes \\
\hline Islamic ideology & + & + & + & & + & & + & & & & + & & + & & + & \\
\hline US troops (dichotomous) & ++ & + & & - & & & & & & & & & & & & - \\
\hline Democracy & & & - & & & & & & & & & & & & & - \\
\hline US troops/Non-democratic state & N/A & & N/A & ++ & N/A & ++ & N/A & ++ & N/A & & N/A & ++ & N/A & ++ & N/A & ++ \\
\hline Log exports to the world (UN) & -- & - & - & -- & -- & -- & -- & -- & - & -- & -- & -- & -- & -- & -- & -- \\
\hline McDonalds (dichotomous) & ++ & ++ & ++ & ++ & ++ & ++ & ++ & ++ & ++ & ++ & ++ & ++ & ++ & ++ & ++ & ++ \\
\hline Organizational membership & & & & & & & & & & & & & & & & \\
\hline Alliance connections & ++ & ++ & ++ & ++ & ++ & ++ & ++ & ++ & ++ & ++ & ++ & ++ & ++ & ++ & ++ & ++ \\
\hline State sponsorship (dichotmous) & & & & & & & & & & & & & & & & \\
\hline Three or fewer attacks & -- & -- & -- & -- & -- & -- & -- & -- & -- & -- & -- & -- & -- & -- & -- & -- \\
\hline Military expenditures per capita & & & & & & & & & & & & & & & & \\
\hline GDP per capita & & & & & & & & & & & & & & & & \\
\hline Years of Internal/external civil war & -- & -- & & & & & & & & & & & & & & \\
\hline
\end{tabular}


Table A.11: Summary of Alternative Specifications of US Troop Cutoff and Definition - Attacking the United States (continued)

Attacking the United States:

Imports from the World

\begin{tabular}{|c|c|c|c|c|c|c|c|c|c|c|c|c|c|c|c|c|}
\hline mports from the World & & & & & & & & & & & & & & & & \\
\hline Cutoff & 100 & 100 & 1000 & 1000 & 2000 & 2000 & 5000 & 5000 & 100 & 100 & 1000 & 1000 & 2000 & 2000 & 5000 & 5000 \\
\hline Islamic ideology & ++ & ++ & ++ & & ++ & & + & + & ++ & & ++ & & ++ & & ++ & + \\
\hline US troops (dichotomous) & ++ & ++ & & & & & & & + & & & & & & & \\
\hline US troops/Non-democratic state & N/A & & N/A & ++ & N/A & ++ & N/A & ++ & N/A & & N/A & ++ & N/A & ++ & N/A & ++ \\
\hline Log imports from the world (UN) & -- & -- & -- & -- & -- & -- & -- & -- & -- & -- & -- & -- & -- & -- & -- & -- \\
\hline McDonalds (dichotomous) & ++ & ++ & ++ & ++ & ++ & ++ & ++ & ++ & ++ & ++ & ++ & ++ & ++ & ++ & ++ & ++ \\
\hline Organizational membership & & & & & & & & & & & & & & & & \\
\hline Alliance connections & ++ & ++ & ++ & ++ & ++ & ++ & ++ & ++ & ++ & ++ & ++ & ++ & ++ & ++ & ++ & ++ \\
\hline Years of Internal/external civil war & -- & - & & & & & & & & & & & & & & \\
\hline
\end{tabular}


Table A.12: Summary of Alternative Specifications of US Troop Cutoff and Definition - Attacking the United States (continued)

Attacking the United States: Penn

World Table - OPENC trade variable

\begin{tabular}{|c|c|c|c|c|c|c|c|c|c|c|c|c|c|c|c|c|}
\hline World Table - OPENC trade variable & & & & & & & & & & & & & & & & \\
\hline Troop variable type & $\operatorname{Max}$ & Max & Max & Max & $\operatorname{Max}$ & $\operatorname{Max}$ & $\operatorname{Max}$ & Max & Avg & Avg & Avg & Avg & Avg & Avg & Avg & Avg \\
\hline Cutoff & 100 & 100 & 1000 & 1000 & 2000 & 2000 & 5000 & 5000 & 100 & 100 & 1000 & 1000 & 2000 & 2000 & 5000 & 5000 \\
\hline Interactions? & No & Yes & No & Yes & No & Yes & No & Yes & No & Yes & No & Yes & No & Yes & No & Yes \\
\hline Islamic ideology & & & & & & & & & & & & & & & & \\
\hline US troops (dichotomous) & ++ & ++ & & + & & + & & - & & & & - & & - & & - \\
\hline Democracy & & & - & & - & & & & & & & & - & & - & - \\
\hline US troops/Non-democratic state & N/A & & N/A & ++ & N/A & ++ & N/A & ++ & N/A & & N/A & ++ & N/A & ++ & N/A & ++ \\
\hline Log OPENC & & & & & & & & & & & & & & & & \\
\hline McDonalds (dichotomous) & ++ & ++ & + & ++ & + & ++ & + & ++ & ++ & ++ & + & ++ & + & ++ & & ++ \\
\hline Organizational membership & & & & & & & & & & & & & & & & \\
\hline Alliance connections & ++ & ++ & ++ & ++ & ++ & ++ & ++ & ++ & ++ & ++ & ++ & ++ & ++ & ++ & ++ & ++ \\
\hline State sponsorship (dichotmous) & & & & & & & & & & & & & & & & \\
\hline Three or fewer attacks & -- & -- & -- & -- & -- & -- & -- & -- & -- & -- & -- & -- & -- & -- & -- & -- \\
\hline Military expenditures per capita & ++ & ++ & & & & & & & + & & & & & & & \\
\hline GDP per capita & - & -- & & & & & & & - & & & & & & & \\
\hline Years of Internal/external civil war & -- & -- & - & & - & & - & - & - & - & - & & - & & - & - \\
\hline
\end{tabular}


Table A.13: Summary of Alternative Specifications of US Troop Cutoff and Definition - Attacking the United States (continued)

\begin{tabular}{|c|c|c|c|c|c|c|c|c|c|c|c|c|c|c|c|c|}
\hline \multicolumn{17}{|l|}{ Attacking the United States: Exports to the US } \\
\hline Troop variable type & $\operatorname{Max}$ & Max & Max & Max & Max & Max & Max & Max & Avg & Avg & Avg & Avg & Avg & Avg & Avg & Avg \\
\hline Cutoff & 100 & 100 & 1000 & 1000 & 2000 & 2000 & 5000 & 5000 & 100 & 100 & 1000 & 1000 & 2000 & 2000 & 5000 & 5000 \\
\hline Interactions? & No & Yes & No & Yes & No & Yes & No & Yes & No & Yes & No & Yes & No & Yes & No & Yes \\
\hline \multicolumn{17}{|l|}{ Islamic ideology } \\
\hline US troops/Non-democratic state & N/A & & N/A & ++ & N/A & ++ & N/A & ++ & N/A & & N/A & ++ & N/A & ++ & N/A & ++ \\
\hline Log exports to US & - & & & - & & - & & & & - & & - & & - & & \\
\hline McDonalds (dichotomous) & ++ & ++ & ++ & ++ & ++ & ++ & ++ & ++ & ++ & ++ & ++ & ++ & ++ & ++ & + & ++ \\
\hline \multicolumn{17}{|l|}{ Organizational membership } \\
\hline Alliance connections & ++ & ++ & ++ & ++ & ++ & ++ & ++ & ++ & ++ & ++ & ++ & ++ & ++ & ++ & ++ & ++ \\
\hline GDP per capita & - & - & & & & & & & & & & & & & & \\
\hline Years of Internal/external civil war & -- & -- & - & & - & & - & & - & & - & & - & & - & \\
\hline
\end{tabular}


Table A.14: Summary of Alternative Specifications of US Troop Cutoff and Definition - Attacking the United States (continued)

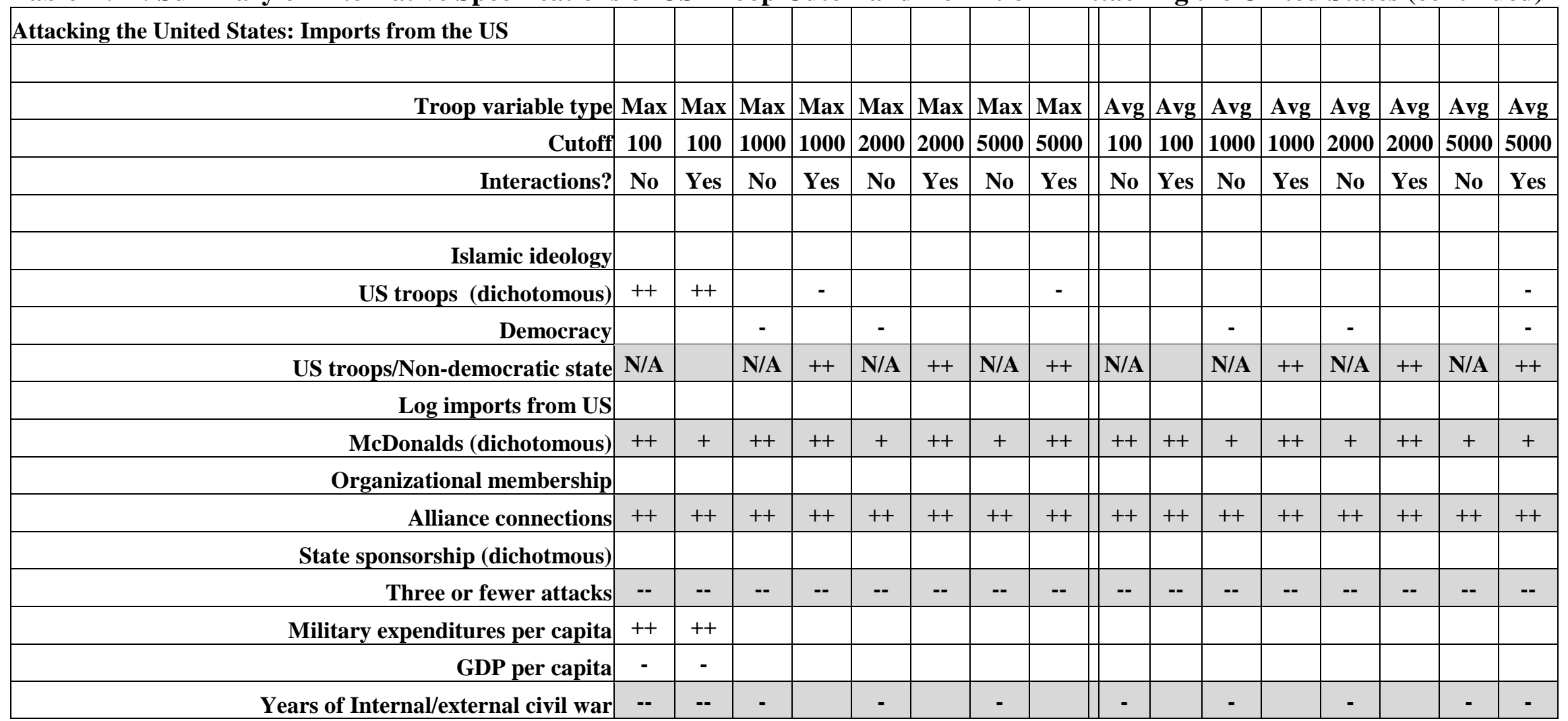


Table A.15: Selected Logit Regressions on Alternative Specifications of US Troop Presence Variable

\begin{tabular}{|c|c|c|c|c|c|c|c|c|}
\hline Cutoff type & Max & Max & Max & Max & Max & Max & Max & Max \\
\hline Cutoff level & 100 & 100 & 100 & 100 & 1000 & 1000 & 1000 & 1000 \\
\hline Dependent variable & Target & Target & Attack & Attack & Target & Target & Attack & Attack \\
\hline Islamic ideology & $\begin{array}{l}1.445 * * \\
(0.666)\end{array}$ & $\begin{array}{c}0.877 \\
(0.601) \\
\end{array}$ & $\begin{array}{l}0.656^{*} \\
(0.391) \\
\end{array}$ & $\begin{array}{l}0.691 * \\
(0.397) \\
\end{array}$ & $\begin{array}{l}0.988 * \\
(0.573) \\
\end{array}$ & $\begin{array}{c}0.864 \\
(0.602) \\
\end{array}$ & $\begin{array}{l}0.710^{*} \\
(0.386) \\
\end{array}$ & $\begin{array}{c}0.554 \\
(0.439) \\
\end{array}$ \\
\hline US troops (dichotomous) & $\begin{array}{c}1.667 * * * \\
(0.602) \\
\end{array}$ & $\begin{array}{c}-0.379 \\
(0.681) \\
\end{array}$ & $\begin{array}{c}0.909 * * \\
(0.405)\end{array}$ & $\begin{array}{l}1.111^{*} \\
(0.598)\end{array}$ & $\begin{array}{c}1.813 * * * \\
(0.550) \\
\end{array}$ & $\begin{array}{c}-0.934 \\
(1.032) \\
\end{array}$ & $\begin{array}{c}-0.137 \\
(0.418) \\
\end{array}$ & $\begin{array}{l}-1.584^{*} \\
(0.891) \\
\end{array}$ \\
\hline Democracy & $\begin{array}{c}-0.440 \\
(0.726)\end{array}$ & $\begin{array}{c}1.447 \\
(1.202) \\
\end{array}$ & $\begin{array}{l}-0.597 \\
(0.524)\end{array}$ & $\begin{array}{c}-0.839 \\
(0.753)\end{array}$ & $\begin{array}{c}0.003 \\
(0.731)\end{array}$ & $\begin{array}{c}1.171 \\
(1.195)\end{array}$ & $\begin{array}{l}-0.812 * \\
(0.488)\end{array}$ & $\begin{array}{l}-0.460 \\
(0.534)\end{array}$ \\
\hline US troops/Non-democratic state & & $\begin{array}{c}3.979 * * * \\
(1.240) \\
\end{array}$ & & $\begin{array}{c}-0.471 \\
(0.896) \\
\end{array}$ & & $\begin{array}{c}4.534 * * * \\
(1.456)\end{array}$ & & $\begin{array}{c}2.762 * * \\
(1.144)\end{array}$ \\
\hline Log exports (UN) & $\begin{array}{l}-0.146 \\
(0.149)\end{array}$ & $\begin{array}{c}-0.311^{* *} \\
(0.131) \\
\end{array}$ & $\begin{array}{c}-0.230 * * \\
(0.113)\end{array}$ & $\begin{array}{l}-0.206^{*} \\
(0.113)\end{array}$ & $\begin{array}{c}-0.209 \\
(0.142)\end{array}$ & $\begin{array}{c}-0.240 * * \\
(0.116)\end{array}$ & $\begin{array}{l}-0.238 * \\
(0.124)\end{array}$ & $\begin{array}{c}-0.248 * * \\
(0.116)\end{array}$ \\
\hline McDonalds (dichotomous) & $\begin{array}{c}-2.053^{* * *} * \\
(0.790)\end{array}$ & $\begin{array}{c}-2.058 * * \\
(0.835) \\
\end{array}$ & $\begin{array}{c}1.190 * * \\
(0.524)\end{array}$ & $\begin{array}{l}1.154 * * \\
(0.510)\end{array}$ & $\begin{array}{c}-1.750 * * \\
(0.754) \\
\end{array}$ & $\begin{array}{c}-1.784^{*} \\
(0.982)\end{array}$ & $\begin{array}{c}1.228 * * \\
(0.607)\end{array}$ & $\begin{array}{c}1.592 * * * \\
(0.568)\end{array}$ \\
\hline Organizational membership & $\begin{array}{c}0.080 \\
(0.353) \\
\end{array}$ & $\begin{array}{c}0.103 \\
(0.399) \\
\end{array}$ & $\begin{array}{c}0.088 \\
(0.223) \\
\end{array}$ & $\begin{array}{c}0.087 \\
(0.223) \\
\end{array}$ & $\begin{array}{c}-0.106 \\
(0.330) \\
\end{array}$ & $\begin{array}{c}0.191 \\
(0.393) \\
\end{array}$ & $\begin{array}{l}-0.026 \\
(0.230) \\
\end{array}$ & $\begin{array}{c}0.026 \\
(0.240) \\
\end{array}$ \\
\hline Alliance connections & $\begin{array}{c}0.157 * * \\
(0.076)\end{array}$ & $\begin{array}{l}0.163^{*} \\
(0.088) \\
\end{array}$ & $\begin{array}{c}0.165 * * \\
(0.070)\end{array}$ & $\begin{array}{c}0.170 * * \\
(0.072)\end{array}$ & $\begin{array}{c}0.164 * * \\
(0.075)\end{array}$ & $\begin{array}{l}0.154 * \\
(0.083)\end{array}$ & $\begin{array}{c}0.192 * * \\
(0.077)\end{array}$ & $\begin{array}{c}0.187 * * \\
(0.078)\end{array}$ \\
\hline State sponsorship (dichotmous) & $\begin{array}{l}-0.787 \\
(0.532)\end{array}$ & $\begin{array}{c}-0.787 \\
(0.548) \\
\end{array}$ & $\begin{array}{c}-0.216 \\
(0.535)\end{array}$ & $\begin{array}{l}-0.233 \\
(0.524)\end{array}$ & $\begin{array}{l}-0.842 \\
(0.533)\end{array}$ & $\begin{array}{c}-0.884 \\
(0.540)\end{array}$ & $\begin{array}{c}-0.346 \\
(0.499)\end{array}$ & $\begin{array}{l}-0.292 \\
(0.512)\end{array}$ \\
\hline Three or fewer attacks & $\begin{array}{l}-0.189 \\
(0.550)\end{array}$ & $\begin{array}{c}-0.233 \\
(0.554) \\
\end{array}$ & $\begin{array}{c}-1.321 * * * \\
(0.331)\end{array}$ & $\begin{array}{c}-1.308 * * * \\
(0.327)\end{array}$ & $\begin{array}{c}-0.169 \\
(0.518)\end{array}$ & $\begin{array}{l}-0.270 \\
(0.569)\end{array}$ & $\begin{array}{c}-1.318 * * * \\
(0.324)\end{array}$ & $\begin{array}{c}-1.444 * * * \\
(0.331) \\
\end{array}$ \\
\hline Military expenditures per capita & $\begin{array}{l}-0.001 \\
(0.002)\end{array}$ & $\begin{array}{l}-0.001 \\
(0.002)\end{array}$ & $\begin{array}{c}0.001 \\
(0.001)\end{array}$ & $\begin{array}{c}0.001 \\
(0.001)\end{array}$ & $\begin{array}{c}0.001 \\
(0.001)\end{array}$ & $\begin{array}{l}-0.002 \\
(0.002)\end{array}$ & $\begin{array}{c}0.001 \\
(0.001)\end{array}$ & $\begin{array}{l}-0.000 \\
(0.001)\end{array}$ \\
\hline GDP per capita & $\begin{array}{c}0.00003 \\
(0.00009) \\
\end{array}$ & $\begin{array}{c}0.00012 \\
(0.00007) \\
\end{array}$ & $\begin{array}{c}-0.00006 \\
(0.00006) \\
\end{array}$ & $\begin{array}{c}-0.00007 \\
(0.00007) \\
\end{array}$ & $\begin{array}{c}-0.00002 \\
(0.00009) \\
\end{array}$ & $\begin{array}{l}0.00013 * \\
(0.00007)\end{array}$ & $\begin{array}{c}-0.00002 \\
(0.00006) \\
\end{array}$ & $\begin{array}{c}0.00004 \\
(0.00005)\end{array}$ \\
\hline Years of internal/external civil war & $\begin{array}{c}-0.275^{* * *} \\
(0.094)\end{array}$ & $\begin{array}{c}-0.336 * * * \\
(0.101)\end{array}$ & $\begin{array}{c}-0.104 * \\
(0.053)\end{array}$ & $\begin{array}{c}-0.111 * * \\
(0.056)\end{array}$ & $\begin{array}{c}-0.283 * * * \\
(0.090)\end{array}$ & $\begin{array}{c}-0.288 * * * \\
(0.096)\end{array}$ & $\begin{array}{c}-0.092 \\
(0.063)\end{array}$ & $\begin{array}{l}-0.052 \\
(0.066)\end{array}$ \\
\hline Constant & $\begin{array}{c}1.421 \\
(3.108)\end{array}$ & $\begin{array}{c}4.066 \\
(2.925)\end{array}$ & $\begin{array}{c}3.547 \\
(2.480)\end{array}$ & $\begin{array}{c}3.186 \\
(2.393)\end{array}$ & $\begin{array}{c}3.199 \\
(3.203)\end{array}$ & $\begin{array}{c}2.396 \\
(2.678)\end{array}$ & $\begin{array}{c}4.232 \\
(2.609)\end{array}$ & $\begin{array}{c}3.605 \\
(2.611) \\
\end{array}$ \\
\hline $\mathbf{N}$ & 387 & 387 & 387 & 387 & 387 & 387 & 387 & 387 \\
\hline Log-likelihood & -86.532 & -80.940 & -145.572 & -145.419 & -86.219 & -79.852 & -148.810 & -144.303 \\
\hline chi2 (Wald) & 254.313 & 425.712 & 87.228 & 107.874 & 205.839 & 527.396 & 54.385 & 74.421 \\
\hline Pseudo R2 (McFadden) & 0.359 & 0.400 & 0.176 & 0.177 & 0.361 & 0.408 & 0.158 & 0.184 \\
\hline AIC & 199.064 & 189.880 & 317.144 & 318.838 & 198.438 & 187.704 & 323.621 & 316.605 \\
\hline BIC & 250.523 & 245.298 & 368.603 & 374.256 & 249.897 & 243.122 & 375.080 & 372.023 \\
\hline
\end{tabular}


Table A.16: Selected Logit Regressions on Alternative Specifications of US Troop Presence Variable (continued)

\begin{tabular}{|c|c|c|c|c|c|c|c|c|}
\hline Cutoff type & Max & Max & Max & Max & Max & Max & Max & Max \\
\hline Cutoff level & 2000 & 2000 & 2000 & 2000 & 5000 & 5000 & 5000 & 5000 \\
\hline Dependent variable & Target & Target & Attack & Attack & Target & Target & Attack & Attack \\
\hline Islamic ideology & $\begin{array}{l}0.944 * \\
(0.538) \\
\end{array}$ & $\begin{array}{l}1.121 * \\
(0.624) \\
\end{array}$ & $\begin{array}{l}0.683 * \\
(0.376) \\
\end{array}$ & $\begin{array}{c}0.586 \\
(0.427) \\
\end{array}$ & $\begin{array}{l}0.941 * \\
(0.558) \\
\end{array}$ & $\begin{array}{l}1.068 * \\
(0.599) \\
\end{array}$ & $\begin{array}{l}0.667 * \\
(0.389) \\
\end{array}$ & $\begin{array}{c}0.629 \\
(0.408) \\
\end{array}$ \\
\hline US troops (dichotomous) & $\begin{array}{c}2.504 * * * \\
(0.627) \\
\end{array}$ & $\begin{array}{c}-0.958 \\
(1.082) \\
\end{array}$ & $\begin{array}{c}0.019 \\
(0.451) \\
\end{array}$ & $\begin{array}{l}-1.471 \\
(0.921) \\
\end{array}$ & $\begin{array}{c}2.723 * * * \\
(0.646) \\
\end{array}$ & $\begin{array}{c}-0.294 \\
(1.199) \\
\end{array}$ & $\begin{array}{c}0.147 \\
(0.577) \\
\end{array}$ & $\begin{array}{l}-2.178 \\
(1.326) \\
\end{array}$ \\
\hline Democracy & $\begin{array}{l}-0.068 \\
(0.664)\end{array}$ & $\begin{array}{c}0.608 \\
(1.067) \\
\end{array}$ & $\begin{array}{l}-0.777 \\
(0.477) \\
\end{array}$ & $\begin{array}{c}-0.641 \\
(0.478) \\
\end{array}$ & $\begin{array}{c}0.086 \\
(0.689)\end{array}$ & $\begin{array}{c}0.659 \\
(1.067) \\
\end{array}$ & $\begin{array}{l}-0.756 \\
(0.482) \\
\end{array}$ & $\begin{array}{l}-0.707 \\
(0.479) \\
\end{array}$ \\
\hline US troops/Non-democratic state & & $\begin{array}{c}5.989 * * * \\
(1.530) \\
\end{array}$ & & $\begin{array}{l}3.048 * * \\
(1.221)\end{array}$ & & $\begin{array}{c}5.339 * * * \\
(1.543) \\
\end{array}$ & & $\begin{array}{l}3.683 * * \\
(1.522)\end{array}$ \\
\hline Log exports (UN) & $\begin{array}{c}-0.308 * * \\
(0.133)\end{array}$ & $\begin{array}{c}-0.423 * * * \\
(0.112)\end{array}$ & $\begin{array}{c}-0.244 * * \\
(0.121)\end{array}$ & $\begin{array}{c}-0.270 * * \\
(0.130)\end{array}$ & $\begin{array}{c}-0.312 * * * \\
(0.118)\end{array}$ & $\begin{array}{c}-0.455^{* * * *} \\
(0.117)\end{array}$ & $\begin{array}{c}-0.251^{* *} \\
(0.120) \\
\end{array}$ & $\begin{array}{c}-0.262 * * \\
(0.124)\end{array}$ \\
\hline McDonalds (dichotomous) & $\begin{array}{l}-0.967 \\
(0.632) \\
\end{array}$ & $\begin{array}{l}-0.058 \\
(0.766) \\
\end{array}$ & $\begin{array}{l}1.274 * * \\
(0.606)\end{array}$ & $\begin{array}{c}2.057 * * * \\
(0.695) \\
\end{array}$ & $\begin{array}{l}-0.743 \\
(0.637) \\
\end{array}$ & $\begin{array}{c}-0.111 \\
(0.760) \\
\end{array}$ & $\begin{array}{l}1.343 * * \\
(0.615)\end{array}$ & $\begin{array}{c}1.961 * * * \\
(0.682)\end{array}$ \\
\hline Organizational membership & $\begin{array}{l}-0.090 \\
(0.345) \\
\end{array}$ & $\begin{array}{c}0.182 \\
(0.423) \\
\end{array}$ & $\begin{array}{l}-0.020 \\
(0.228) \\
\end{array}$ & $\begin{array}{l}-0.006 \\
(0.241) \\
\end{array}$ & $\begin{array}{l}-0.120 \\
(0.345) \\
\end{array}$ & $\begin{array}{c}0.154 \\
(0.410) \\
\end{array}$ & $\begin{array}{l}-0.022 \\
(0.231) \\
\end{array}$ & $\begin{array}{c}0.072 \\
(0.232) \\
\end{array}$ \\
\hline Alliance connections & $\begin{array}{l}0.145 * * \\
(0.068)\end{array}$ & $\begin{array}{l}0.132 * \\
(0.077) \\
\end{array}$ & $\begin{array}{c}0.186^{* *} \\
(0.075)\end{array}$ & $\begin{array}{l}0.190 * * \\
(0.080)\end{array}$ & $\begin{array}{c}0.140 * * \\
(0.068)\end{array}$ & $\begin{array}{l}0.129 * \\
(0.074) \\
\end{array}$ & $\begin{array}{c}0.182 * * \\
(0.074)\end{array}$ & $\begin{array}{l}0.175 * * \\
(0.074)\end{array}$ \\
\hline State sponsorship (dichotmous) & $\begin{array}{l}-0.943^{*} \\
(0.547)\end{array}$ & $\begin{array}{l}-0.900 \\
(0.600)\end{array}$ & $\begin{array}{c}-0.344 \\
(0.505) \\
\end{array}$ & $\begin{array}{l}-0.235 \\
(0.524)\end{array}$ & $\begin{array}{l}-0.925 \\
(0.563) \\
\end{array}$ & $\begin{array}{l}-0.910 \\
(0.605)\end{array}$ & $\begin{array}{l}-0.339 \\
(0.503)\end{array}$ & $\begin{array}{l}-0.307 \\
(0.549) \\
\end{array}$ \\
\hline Three or fewer attacks & $\begin{array}{l}-0.229 \\
(0.542)\end{array}$ & $\begin{array}{l}-0.387 \\
(0.658) \\
\end{array}$ & $\begin{array}{c}-1.318^{* * *} \\
(0.322)\end{array}$ & $\begin{array}{c}-1.458 * * * \\
(0.336)\end{array}$ & $\begin{array}{l}-0.299 \\
(0.537) \\
\end{array}$ & $\begin{array}{c}-0.401 \\
(0.631)\end{array}$ & $\begin{array}{c}-1.325 * * * \\
(0.324)\end{array}$ & $\begin{array}{c}-1.415 * * * \\
(0.329) \\
\end{array}$ \\
\hline Military expenditures per capita & $\begin{array}{c}0.001 \\
(0.002) \\
\end{array}$ & $\begin{array}{c}-0.004 * * \\
(0.002)\end{array}$ & $\begin{array}{c}0.001 \\
(0.001) \\
\end{array}$ & $\begin{array}{l}-0.000 \\
(0.001) \\
\end{array}$ & $\begin{array}{c}0.000 \\
(0.002) \\
\end{array}$ & $\begin{array}{c}-0.003 * * \\
(0.002)\end{array}$ & $\begin{array}{c}0.001 \\
(0.001) \\
\end{array}$ & $\begin{array}{l}-0.000 \\
(0.001) \\
\end{array}$ \\
\hline GDP per capita & $\begin{array}{c}-0.00005 \\
(0.00009) \\
\end{array}$ & $\begin{array}{c}0.00019 * * \\
(0.00007)\end{array}$ & $\begin{array}{c}-0.00002 \\
(0.00006) \\
\end{array}$ & $\begin{array}{c}0.00004 \\
(0.00005) \\
\end{array}$ & $\begin{array}{l}-0.00005 \\
(0.00009) \\
\end{array}$ & $\begin{array}{c}0.00017 * * \\
(0.00008) \\
\end{array}$ & $\begin{array}{l}-0.00003 \\
(0.00006) \\
\end{array}$ & $\begin{array}{c}0.00004 \\
(0.00005) \\
\end{array}$ \\
\hline Years of internal/external civil war & $\begin{array}{c}-0.347 * * * \\
(0.087)\end{array}$ & $\begin{array}{c}-0.463 * * * \\
(0.114)\end{array}$ & $\begin{array}{l}-0.092 \\
(0.064) \\
\end{array}$ & $\begin{array}{l}-0.050 \\
(0.067) \\
\end{array}$ & $\begin{array}{c}-0.319 * * * \\
(0.081)\end{array}$ & $\begin{array}{c}-0.476^{* * * *} \\
(0.115) \\
\end{array}$ & $\begin{array}{l}-0.091 \\
(0.063) \\
\end{array}$ & $\begin{array}{c}-0.071 \\
(0.060)\end{array}$ \\
\hline Constant & $\begin{array}{l}5.288 * \\
(3.120)\end{array}$ & $\begin{array}{l}5.795 * * \\
(2.587)\end{array}$ & $\begin{array}{l}4.313 * \\
(2.587)\end{array}$ & $\begin{array}{c}3.833 \\
(2.802)\end{array}$ & $\begin{array}{l}5.239 * \\
(2.815)\end{array}$ & $\begin{array}{c}6.639 * * * \\
(2.554)\end{array}$ & $\begin{array}{l}4.438 * \\
(2.572)\end{array}$ & $\begin{array}{c}3.687 \\
(2.689) \\
\end{array}$ \\
\hline $\mathbf{N}$ & 387 & 387 & 387 & 387 & 387 & 387 & 387 & 387 \\
\hline Log-likelihood & -83.355 & -74.894 & -148.865 & -144.178 & -81.983 & -75.271 & -148.826 & -143.861 \\
\hline chi2 (Wald) & 232.445 & 604.187 & 56.518 & 70.394 & 300.405 & 557.335 & 57.375 & 77.005 \\
\hline Pseudo R2 (McFadden) & 0.383 & 0.445 & 0.158 & 0.184 & 0.393 & 0.442 & 0.158 & 0.186 \\
\hline AIC & 192.711 & 177.788 & 323.730 & 316.357 & 189.965 & 178.543 & 323.653 & 315.722 \\
\hline BIC & 244.170 & 233.206 & 375.189 & 371.775 & 241.425 & 233.961 & 375.112 & 371.140 \\
\hline
\end{tabular}

Table A.17: Selected Logit Regressions on Alternative Specifications of US Troop Presence Variable (continued) 


\begin{tabular}{|c|c|c|c|c|c|c|c|c|}
\hline Cutoff type & Avg & Avg & Avg & Avg & Avg & Avg & Avg & Avg \\
\hline Cutoff level & 100 & 100 & 100 & 100 & 1000 & 1000 & 1000 & 1000 \\
\hline Dependent variable & Target & Target & Attack & Attack & Target & Target & Attack & Attack \\
\hline Islamic ideology & $\begin{array}{c}1.318 * * \\
(0.658)\end{array}$ & $\begin{array}{c}0.776 \\
(0.582)\end{array}$ & $\begin{array}{c}0.643 \\
(0.392)\end{array}$ & $\begin{array}{c}0.522 \\
(0.428)\end{array}$ & $\begin{array}{l}0.944 * \\
(0.538)\end{array}$ & $\begin{array}{l}1.121 * \\
(0.624)\end{array}$ & $\begin{array}{l}0.683 * \\
(0.376)\end{array}$ & $\begin{array}{c}0.586 \\
(0.427)\end{array}$ \\
\hline US troops (dichotomous) & $\begin{array}{c}1.824 * * * \\
(0.572)\end{array}$ & $\begin{array}{c}-0.214 \\
(0.679)\end{array}$ & $\begin{array}{c}0.472 \\
(0.358)\end{array}$ & $\begin{array}{c}0.067 \\
(0.524)\end{array}$ & $\begin{array}{c}2.504 * * * \\
(0.627)\end{array}$ & $\begin{array}{c}-0.958 \\
(1.082)\end{array}$ & $\begin{array}{c}0.019 \\
(0.451)\end{array}$ & $\begin{array}{l}-1.471 \\
(0.921)\end{array}$ \\
\hline Democracy & $\begin{array}{c}-0.381 \\
(0.768)\end{array}$ & $\begin{array}{c}1.240 \\
(1.185) \\
\end{array}$ & $\begin{array}{c}-0.736 \\
(0.494)\end{array}$ & $\begin{array}{l}-0.492 \\
(0.557)\end{array}$ & $\begin{array}{c}-0.068 \\
(0.664)\end{array}$ & $\begin{array}{c}0.608 \\
(1.067)\end{array}$ & $\begin{array}{l}-0.777 \\
(0.477)\end{array}$ & $\begin{array}{c}-0.641 \\
(0.478)\end{array}$ \\
\hline US troops/Non-democratic state & & $\begin{array}{c}3.851 * * * \\
(1.248) \\
\end{array}$ & & $\begin{array}{c}1.047 \\
(0.888) \\
\end{array}$ & & $\begin{array}{c}5.989 * * * \\
(1.530) \\
\end{array}$ & & $\begin{array}{l}3.048 * * \\
(1.221)\end{array}$ \\
\hline Log exports (UN) & $\begin{array}{l}-0.120 \\
(0.139)\end{array}$ & $\begin{array}{c}-0.285^{* *} \\
(0.125)\end{array}$ & $\begin{array}{l}-0.228 * \\
(0.123)\end{array}$ & $\begin{array}{c}-0.267 * * \\
(0.123)\end{array}$ & $\begin{array}{c}-0.308 * * \\
(0.133)\end{array}$ & $\begin{array}{c}-0.423 * * * \\
(0.112)\end{array}$ & $\begin{array}{c}-0.244 * * \\
(0.121)\end{array}$ & $\begin{array}{c}-0.270 * * \\
(0.130)\end{array}$ \\
\hline McDonalds (dichotomous) & $\begin{array}{c}-1.816^{* *} \\
(0.818) \\
\end{array}$ & $\begin{array}{c}-1.802 * \\
(0.969)\end{array}$ & $\begin{array}{l}1.362 * * \\
(0.546)\end{array}$ & $\begin{array}{c}1.591 * * * \\
(0.568) \\
\end{array}$ & $\begin{array}{l}-0.967 \\
(0.632) \\
\end{array}$ & $\begin{array}{c}-0.058 \\
(0.766) \\
\end{array}$ & $\begin{array}{c}1.274 * * \\
(0.606)\end{array}$ & $\begin{array}{c}2.057 * * * \\
(0.695)\end{array}$ \\
\hline Organizational membership & $\begin{array}{c}0.103 \\
(0.353) \\
\end{array}$ & $\begin{array}{c}0.128 \\
(0.395) \\
\end{array}$ & $\begin{array}{c}0.037 \\
(0.221) \\
\end{array}$ & $\begin{array}{c}0.026 \\
(0.220) \\
\end{array}$ & $\begin{array}{c}-0.090 \\
(0.345) \\
\end{array}$ & $\begin{array}{c}0.182 \\
(0.423) \\
\end{array}$ & $\begin{array}{c}-0.020 \\
(0.228) \\
\end{array}$ & $\begin{array}{c}-0.006 \\
(0.241) \\
\end{array}$ \\
\hline Alliance connections & $\begin{array}{c}0.147 * * \\
(0.072)\end{array}$ & $\begin{array}{l}0.154 * \\
(0.083)\end{array}$ & $\begin{array}{c}0.167 * * \\
(0.074)\end{array}$ & $\begin{array}{c}0.162 * * \\
(0.070)\end{array}$ & $\begin{array}{c}0.145 * * \\
(0.068)\end{array}$ & $\begin{array}{l}0.132 * \\
(0.077)\end{array}$ & $\begin{array}{c}0.186 * * \\
(0.075)\end{array}$ & $\begin{array}{c}0.190 * * \\
(0.080)\end{array}$ \\
\hline State sponsorship (dichotmous) & $\begin{array}{l}-0.795 \\
(0.518)\end{array}$ & $\begin{array}{c}-0.881 * \\
(0.532)\end{array}$ & $\begin{array}{l}-0.308 \\
(0.516)\end{array}$ & $\begin{array}{c}-0.314 \\
(0.528)\end{array}$ & $\begin{array}{l}-0.943 * \\
(0.547)\end{array}$ & $\begin{array}{l}-0.900 \\
(0.600)\end{array}$ & $\begin{array}{c}-0.344 \\
(0.505)\end{array}$ & $\begin{array}{l}-0.235 \\
(0.524)\end{array}$ \\
\hline Three or fewer attacks & $\begin{array}{c}-0.231 \\
(0.551)\end{array}$ & $\begin{array}{l}-0.273 \\
(0.560)\end{array}$ & $\begin{array}{c}-1.349 * * * \\
(0.331)\end{array}$ & $\begin{array}{c}-1.378 * * * \\
(0.324)\end{array}$ & $\begin{array}{l}-0.229 \\
(0.542)\end{array}$ & $\begin{array}{c}-0.387 \\
(0.658)\end{array}$ & $\begin{array}{c}-1.318 * * * \\
(0.322)\end{array}$ & $\begin{array}{c}-1.458 * * * \\
(0.336)\end{array}$ \\
\hline Military expenditures per capita & $\begin{array}{c}-0.001 \\
(0.002) \\
\end{array}$ & $\begin{array}{c}-0.001 \\
(0.002)\end{array}$ & $\begin{array}{c}0.001 \\
(0.001) \\
\end{array}$ & $\begin{array}{c}0.001 \\
(0.001) \\
\end{array}$ & $\begin{array}{c}0.001 \\
(0.002) \\
\end{array}$ & $\begin{array}{c}-0.004 * * \\
(0.002)\end{array}$ & $\begin{array}{c}0.001 \\
(0.001)\end{array}$ & $\begin{array}{c}-0.000 \\
(0.001)\end{array}$ \\
\hline GDP per capita & $\begin{array}{c}0.000 \\
(0.000) \\
\end{array}$ & $\begin{array}{c}0.000 \\
(0.000) \\
\end{array}$ & $\begin{array}{c}-0.000 \\
(0.000)\end{array}$ & $\begin{array}{l}-0.000 \\
(0.000) \\
\end{array}$ & $\begin{array}{l}-0.000 \\
(0.000)\end{array}$ & $\begin{array}{c}0.000 * * \\
(0.000)\end{array}$ & $\begin{array}{l}-0.000 \\
(0.000) \\
\end{array}$ & $\begin{array}{c}0.000 \\
(0.000) \\
\end{array}$ \\
\hline Years of internal/external civil war & $\begin{array}{c}-0.247 * * * \\
(0.095)\end{array}$ & $\begin{array}{c}-0.307 * * * \\
(0.092) \\
\end{array}$ & $\begin{array}{c}-0.085 \\
(0.060)\end{array}$ & $\begin{array}{c}-0.075 \\
(0.064)\end{array}$ & $\begin{array}{c}-0.347 * * * \\
(0.087)\end{array}$ & $\begin{array}{c}-0.463 * * * \\
(0.114)\end{array}$ & $\begin{array}{l}-0.092 \\
(0.064)\end{array}$ & $\begin{array}{c}-0.050 \\
(0.067) \\
\end{array}$ \\
\hline Constant & $\begin{array}{c}0.827 \\
(2.984) \\
\end{array}$ & $\begin{array}{c}3.560 \\
(2.818) \\
\end{array}$ & $\begin{array}{c}3.755 \\
(2.649) \\
\end{array}$ & $\begin{array}{c}4.267 \\
(2.676) \\
\end{array}$ & $\begin{array}{l}5.288 * \\
(3.120)\end{array}$ & $\begin{array}{l}5.795 * * \\
(2.587)\end{array}$ & $\begin{array}{l}4.313 * \\
(2.587) \\
\end{array}$ & $\begin{array}{c}3.833 \\
(2.802) \\
\end{array}$ \\
\hline $\mathbf{N}$ & 387 & 387 & 387 & 387 & 387 & 387 & 387 & 387 \\
\hline Log-likelihood & -85.255 & -80.251 & -148.049 & -147.197 & -83.355 & -74.894 & -148.865 & -144.178 \\
\hline chi2 & 286.975 & 541.779 & 72.15 & 77.222 & 232.445 & 604.187 & 56.518 & 70.394 \\
\hline Pseudo R2 (McFadden) & 0.368 & 0.406 & 0.162 & 0.167 & 0.383 & 0.445 & 0.158 & 0.184 \\
\hline AIC & 196.51 & 188.502 & 322.099 & 322.395 & 192.711 & 177.788 & 323.73 & 316.357 \\
\hline BIC & 247.969 & 243.92 & 373.558 & 377.812 & 244.17 & 233.206 & 375.189 & 371.775 \\
\hline
\end{tabular}

Table A.18: Selected Logit Regressions on Alternative Specifications of US Troop Presence Variable (continued)

\begin{tabular}{|r|c|c|c|c|c|c|c|c|}
\hline Cutoff type & Avg & Avg & Avg & Avg & Avg & Avg & Avg & Avg \\
\hline Cutoff level & $\mathbf{2 0 0 0}$ & $\mathbf{2 0 0 0}$ & $\mathbf{2 0 0 0}$ & $\mathbf{2 0 0 0}$ & $\mathbf{5 0 0 0}$ & $\mathbf{5 0 0 0}$ & $\mathbf{5 0 0 0}$ & $\mathbf{5 0 0 0}$ \\
\hline Dependent variable & Target & Target & Attack & Attack & Target & Target & Attack & Attack \\
\hline
\end{tabular}




\begin{tabular}{|c|c|c|c|c|c|c|c|c|}
\hline Islamic ideology & $\begin{array}{c}0.944 * \\
(0.538) \\
\end{array}$ & $\begin{array}{c}1.121 * \\
(0.624) \\
\end{array}$ & $\begin{array}{c}0.683 * \\
(0.376) \\
\end{array}$ & $\begin{array}{c}0.586 \\
(0.427) \\
\end{array}$ & $\begin{array}{c}1.039 * \\
(0.564) \\
\end{array}$ & $\begin{array}{c}1.268 * \\
(0.669) \\
\end{array}$ & $\begin{array}{l}0.679 * \\
(0.387) \\
\end{array}$ & $\begin{array}{c}0.651 \\
(0.402) \\
\end{array}$ \\
\hline US troops (dichotomous) & $\begin{array}{c}2.504 * * * \\
(0.627)\end{array}$ & $\begin{array}{c}-0.958 \\
(1.082) \\
\end{array}$ & $\begin{array}{c}0.019 \\
(0.451) \\
\end{array}$ & $\begin{array}{c}-1.471 \\
(0.921) \\
\end{array}$ & $\begin{array}{c}2.607 * * * \\
(0.648)\end{array}$ & $\begin{array}{l}-0.237 \\
(1.183)\end{array}$ & $\begin{array}{c}0.053 \\
(0.626) \\
\end{array}$ & $\begin{array}{l}-2.193 * \\
(1.329)\end{array}$ \\
\hline Democracy & $\begin{array}{c}-0.068 \\
(0.664) \\
\end{array}$ & $\begin{array}{c}0.608 \\
(1.067) \\
\end{array}$ & $\begin{array}{c}-0.777 \\
(0.477) \\
\end{array}$ & $\begin{array}{c}-0.641 \\
(0.478) \\
\end{array}$ & $\begin{array}{l}-0.230 \\
(0.680) \\
\end{array}$ & $\begin{array}{c}0.010 \\
(0.974) \\
\end{array}$ & $\begin{array}{c}-0.774 \\
(0.481) \\
\end{array}$ & $\begin{array}{l}-0.821 * \\
(0.482)\end{array}$ \\
\hline US troops/Non-democratic state & & $\begin{array}{c}5.989 * * * \\
(1.530) \\
\end{array}$ & & $\begin{array}{l}3.048 * * \\
(1.221)\end{array}$ & & $\begin{array}{c}4.480 * * * \\
(1.443) \\
\end{array}$ & & $\begin{array}{l}3.751 * * \\
(1.594)\end{array}$ \\
\hline Log exports (UN) & $\begin{array}{c}-0.308 * * \\
(0.133)\end{array}$ & $\begin{array}{c}-0.423 * * * \\
(0.112)\end{array}$ & $\begin{array}{c}-0.244 * * \\
(0.121)\end{array}$ & $\begin{array}{c}-0.270^{* *} \\
(0.130)\end{array}$ & $\begin{array}{c}-0.284 * * \\
(0.128)\end{array}$ & $\begin{array}{c}-0.328 * * * \\
(0.121)\end{array}$ & $\begin{array}{c}-0.245^{* *} \\
(0.120)\end{array}$ & $\begin{array}{c}-0.252^{* *} \\
(0.123)\end{array}$ \\
\hline McDonalds (dichotomous) & $\begin{array}{c}-0.967 \\
(0.632) \\
\end{array}$ & $\begin{array}{c}-0.058 \\
(0.766) \\
\end{array}$ & $\begin{array}{c}1.274 * * \\
(0.606)\end{array}$ & $\begin{array}{c}2.057 * * * \\
(0.695) \\
\end{array}$ & $\begin{array}{l}-0.590 \\
(0.694) \\
\end{array}$ & $\begin{array}{c}0.013 \\
(0.838) \\
\end{array}$ & $\begin{array}{c}1.295 * * \\
(0.636)\end{array}$ & $\begin{array}{c}2.088 * * \\
(0.824)\end{array}$ \\
\hline Organizational membership & $\begin{array}{c}-0.090 \\
(0.345) \\
\end{array}$ & $\begin{array}{c}0.182 \\
(0.423) \\
\end{array}$ & $\begin{array}{c}-0.020 \\
(0.228) \\
\end{array}$ & $\begin{array}{c}-0.006 \\
(0.241) \\
\end{array}$ & $\begin{array}{c}-0.070 \\
(0.345) \\
\end{array}$ & $\begin{array}{c}0.213 \\
(0.419) \\
\end{array}$ & $\begin{array}{c}-0.021 \\
(0.231) \\
\end{array}$ & $\begin{array}{c}0.094 \\
(0.235) \\
\end{array}$ \\
\hline Alliance connections & $\begin{array}{c}0.145 * * \\
(0.068)\end{array}$ & $\begin{array}{l}0.132 * \\
(0.077) \\
\end{array}$ & $\begin{array}{c}0.186 * * \\
(0.075)\end{array}$ & $\begin{array}{c}0.190 * * \\
(0.080)\end{array}$ & $\begin{array}{c}0.134 * * \\
(0.066)\end{array}$ & $\begin{array}{c}0.120 * \\
(0.070) \\
\end{array}$ & $\begin{array}{c}0.185 * * \\
(0.074)\end{array}$ & $\begin{array}{c}0.171 * * \\
(0.075)\end{array}$ \\
\hline State sponsorship (dichotmous) & $\begin{array}{c}-0.943 * \\
(0.547)\end{array}$ & $\begin{array}{c}-0.900 \\
(0.600)\end{array}$ & $\begin{array}{c}-0.344 \\
(0.505)\end{array}$ & $\begin{array}{l}-0.235 \\
(0.524)\end{array}$ & $\begin{array}{c}-1.001 * \\
(0.554)\end{array}$ & $\begin{array}{c}-1.079 * \\
(0.639)\end{array}$ & $\begin{array}{c}-0.343 \\
(0.504)\end{array}$ & $\begin{array}{l}-0.342 \\
(0.563)\end{array}$ \\
\hline Three or fewer attacks & $\begin{array}{l}-0.229 \\
(0.542) \\
\end{array}$ & $\begin{array}{c}-0.387 \\
(0.658) \\
\end{array}$ & $\begin{array}{c}-1.318 * * * \\
(0.322) \\
\end{array}$ & $\begin{array}{c}-1.458 * * * \\
(0.336) \\
\end{array}$ & $\begin{array}{l}-0.233 \\
(0.563) \\
\end{array}$ & $\begin{array}{l}-0.332 \\
(0.639) \\
\end{array}$ & $\begin{array}{c}-1.320 * * * \\
(0.323) \\
\end{array}$ & $\begin{array}{c}-1.409 * * * * \\
(0.330)\end{array}$ \\
\hline Military expenditures per capita & $\begin{array}{c}0.001 \\
(0.002)\end{array}$ & $\begin{array}{c}-0.004 * * \\
(0.002)\end{array}$ & $\begin{array}{c}0.001 \\
(0.001)\end{array}$ & $\begin{array}{c}-0.000 \\
(0.001)\end{array}$ & $\begin{array}{c}0.001 \\
(0.002)\end{array}$ & $\begin{array}{c}-0.001 \\
(0.002)\end{array}$ & $\begin{array}{c}0.001 \\
(0.001)\end{array}$ & $\begin{array}{c}0.000 \\
(0.001)\end{array}$ \\
\hline GDP per capita & $\begin{array}{l}-0.000 \\
(0.000)\end{array}$ & $\begin{array}{c}0.000 * * \\
(0.000)\end{array}$ & $\begin{array}{l}-0.000 \\
(0.000)\end{array}$ & $\begin{array}{c}0.000 \\
(0.000) \\
\end{array}$ & $\begin{array}{l}-0.000 \\
(0.000)\end{array}$ & $\begin{array}{c}0.000 \\
(0.000) \\
\end{array}$ & $\begin{array}{l}-0.000 \\
(0.000)\end{array}$ & $\begin{array}{c}0.000 \\
(0.000) \\
\end{array}$ \\
\hline Years of internal/external civil war & $\begin{array}{c}-0.347 * * * \\
(0.087) \\
\end{array}$ & $\begin{array}{c}-0.463 * * * \\
(0.114) \\
\end{array}$ & $\begin{array}{l}-0.092 \\
(0.064)\end{array}$ & $\begin{array}{l}-0.050 \\
(0.067)\end{array}$ & $\begin{array}{c}-0.339 * * * \\
(0.106) \\
\end{array}$ & $\begin{array}{c}-0.394 * * * \\
(0.097) \\
\end{array}$ & $\begin{array}{c}-0.092 \\
(0.063) \\
\end{array}$ & $\begin{array}{l}-0.080 \\
(0.059) \\
\end{array}$ \\
\hline Constant & $\begin{array}{l}5.288 * \\
(3.120) \\
\end{array}$ & $\begin{array}{c}5.795 * * \\
(2.587)\end{array}$ & $\begin{array}{l}4.313^{*} \\
(2.587)\end{array}$ & $\begin{array}{c}3.833 \\
(2.802) \\
\end{array}$ & $\begin{array}{c}4.608 \\
(3.069) \\
\end{array}$ & $\begin{array}{c}4.036 \\
(2.874) \\
\end{array}$ & $\begin{array}{l}4.338 * \\
(2.565) \\
\end{array}$ & $\begin{array}{c}3.444 \\
(2.694) \\
\end{array}$ \\
\hline $\mathbf{N}$ & 387 & 387 & 387 & 387 & 387 & 387 & 387 & 387 \\
\hline Log-likelihood & -83.355 & -74.894 & -148.865 & -144.178 & -83.199 & -77.886 & -148.861 & -144.052 \\
\hline chi2 & 232.445 & 604.187 & 56.518 & 70.394 & 269.574 & 802.706 & 56.653 & 74.08 \\
\hline Pseudo R2 (McFadden) & 0.383 & 0.445 & 0.158 & 0.184 & 0.384 & 0.423 & 0.158 & 0.185 \\
\hline AIC & 192.711 & 177.788 & 323.73 & 316.357 & 192.398 & 183.773 & 323.722 & 316.103 \\
\hline BIC & 244.17 & 233.206 & 375.189 & 371.775 & 243.857 & 239.191 & 375.181 & 371.521 \\
\hline
\end{tabular}

Table A.19: Selected Predict Probabilities, Selected Alternative Specifications of Troop Presence Variable

\begin{tabular}{|c|c|c|c|c|c|c|c|c|}
\hline & Targeting & Targeting & Attacking & Attacking & Targeting & Targeting & Attacking & Attacking \\
\hline & No & With & No & With & No & With & No & With \\
\hline & Interactive & Interactive & Interactive & Interactive & Interactive & Interactive & Interactive & Interactive \\
\hline & $\operatorname{Max} 100$ & Max 100 & Max 100 & Max 100 & Max 1000 & Max 1000 & Max 1000 & Max 1000 \\
\hline Probability at the means & 0.0371 & 0.0324 & 0.1283 & 0.1273 & 0.0398 & 0.0326 & 0.1370 & 0.1275 \\
\hline
\end{tabular}




\begin{tabular}{|c|c|c|c|c|c|c|c|c|}
\hline \multicolumn{9}{|l|}{ Islamic ideology } \\
\hline Yes & 0.0984 & NS & 0.1911 & 0.1935 & 0.0780 & NS & 0.2094 & NS \\
\hline No & 0.0251 & NS & 0.1092 & 0.1074 & 0.0305 & NS & 0.1152 & NS \\
\hline \multicolumn{9}{|l|}{ US troops (dichotomous) } \\
\hline Yes & 0.0732 & NS & 0.1790 & 0.1906 & 0.1362 & NS & NS & 0.0435 \\
\hline $\mathrm{No}$ & 0.0147 & NS & 0.0807 & 0.0720 & 0.0251 & NS & NS & 0.1816 \\
\hline \multicolumn{9}{|l|}{ US troops/Non-democratic state } \\
\hline Yes & N/A & 0.5019 & N/A & NS & N/A & 0.6518 & N/A & 0.6282 \\
\hline No & N/A & 0.0185 & N/A & NS & N/A & 0.0197 & N/A & 0.0965 \\
\hline \multicolumn{9}{|l|}{ Log exports (UN) } \\
\hline+1 std. deviation & NS & 0.0182 & 0.0865 & 0.0895 & NS & 0.0208 & 0.0915 & 0.0834 \\
\hline-1 std. deviation & NS & 0.0549 & 0.1812 & 0.1735 & NS & 0.0489 & 0.1947 & 0.1846 \\
\hline \multicolumn{9}{|l|}{ McDonalds (dichotomous) } \\
\hline Yes & 0.0249 & 0.0218 & 0.1572 & 0.1550 & 0.0285 & 0.0231 & 0.1686 & 0.1671 \\
\hline No & 0.1662 & 0.1485 & 0.0537 & 0.0547 & 0.1443 & 0.1232 & 0.0560 & 0.0392 \\
\hline \multicolumn{9}{|l|}{ Alliance connections } \\
\hline No connections & 0.0299 & 0.0260 & 0.1044 & 0.1029 & 0.0319 & 0.0264 & 0.1081 & 0.1009 \\
\hline+1 std. deviation & 0.0541 & 0.0481 & 0.1825 & 0.1829 & 0.0590 & 0.0473 & 0.2047 & 0.1897 \\
\hline+2 std. deviation & 0.0786 & 0.0710 & 0.2537 & 0.2565 & 0.0870 & 0.0685 & 0.2953 & 0.2735 \\
\hline \multicolumn{9}{|l|}{ Three or fewer attacks } \\
\hline Yes & NS & NS & 0.0950 & 0.0945 & NS & NS & 0.1018 & 0.0917 \\
\hline No & NS & NS & 0.2824 & 0.2785 & NS & NS & 0.2975 & 0.2998 \\
\hline \multicolumn{9}{|l|}{ Years of internal/external civil war } \\
\hline No years & 0.0761 & 0.0783 & 0.1641 & 0.1655 & 0.0833 & 0.0695 & NS & NS \\
\hline+1 std. deviation & 0.0146 & 0.0104 & 0.0931 & 0.0903 & 0.0153 & 0.0122 & NS & NS \\
\hline
\end{tabular}


Table A.20: Selected Predict Probabilities, Selected Alternative Specifications of Troop Presence Variable (continued)

\begin{tabular}{|c|c|c|c|c|c|c|c|c|}
\hline Main Models & Targeting & Targeting & Attacking & Attacking & Targeting & Targeting & Attacking & Attacking \\
\hline & No & With & No & With & No & With & No & With \\
\hline & Interactive & Interactive & Interactive & Interactive & Interactive & Interactive & Interactive & Interactive \\
\hline & Max 2000 & Max 2000 & Max 2000 & Max 2000 & Max 5000 & Max 5000 & Max 5000 & Max 5000 \\
\hline Probability at the means & 0.0351 & 0.0191 & 0.1370 & 0.1267 & 0.0340 & 0.0194 & 0.1369 & 0.1229 \\
\hline \multicolumn{9}{|l|}{ Islamic ideology } \\
\hline Yes & 0.0671 & 0.0419 & 0.2062 & NS & 0.0649 & 0.0410 & 0.2041 & NS \\
\hline No & 0.0272 & 0.0141 & 0.1160 & NS & 0.0264 & 0.0145 & 0.1164 & NS \\
\hline \multicolumn{9}{|l|}{ US troops (dichotomous) } \\
\hline Yes & 0.1950 & NS & NS & NS & 0.2364 & NS & NS & NS \\
\hline No & 0.0194 & NS & NS & NS & 0.0199 & NS & NS & NS \\
\hline \multicolumn{9}{|l|}{ US troops/Non-democratic state } \\
\hline Yes & N/A & 0.8096 & N/A & 0.6921 & N/A & 0.7065 & N/A & 0.7936 \\
\hline No & N/A & 0.0105 & N/A & 0.0964 & N/A & 0.0114 & N/A & 0.0881 \\
\hline \multicolumn{9}{|l|}{ Log exports (UN) } \\
\hline+1 std. deviation & 0.0198 & 0.0086 & 0.0905 & 0.0796 & 0.0190 & 0.0082 & 0.0893 & 0.0782 \\
\hline -1 std. deviation & 0.0591 & 0.0395 & 0.1963 & 0.1896 & 0.0576 & 0.0424 & 0.1983 & 0.1821 \\
\hline \multicolumn{9}{|l|}{ McDonalds (dichotomous) } \\
\hline Yes & NS & NS & 0.1698 & 0.1793 & NS & NS & 0.1716 & 0.1715 \\
\hline No & NS & NS & 0.0541 & 0.0272 & NS & NS & 0.0513 & 0.0283 \\
\hline \multicolumn{9}{|l|}{ Alliance connections } \\
\hline No connections & 0.0288 & 0.0159 & 0.1089 & 0.0999 & 0.0281 & 0.0162 & 0.1092 & 0.0987 \\
\hline+1 std. deviation & 0.0498 & 0.0265 & 0.2022 & 0.1897 & 0.0478 & 0.0267 & 0.2007 & 0.1787 \\
\hline+2 std. deviation & 0.0705 & 0.0367 & 0.2888 & 0.2752 & 0.0669 & 0.0367 & 0.2854 & 0.2533 \\
\hline \multicolumn{9}{|l|}{ Three or fewer attacks } \\
\hline Yes & NS & NS & 0.1018 & 0.0908 & NS & NS & 0.1015 & 0.0889 \\
\hline No & NS & NS & 0.2975 & 0.3003 & NS & NS & 0.2984 & 0.2865 \\
\hline \multicolumn{9}{|l|}{ Years of internal/external civil war } \\
\hline No years & 0.0869 & 0.0656 & NS & NS & 0.0785 & 0.0688 & NS & NS \\
\hline+1 std. deviation & 0.0108 & 0.0039 & NS & NS & 0.0115 & 0.0038 & NS & NS \\
\hline
\end{tabular}


Table A.21: Selected Specifications of Troop Presence Variable When Excluding Iraqi and Afghani Orgs.

\begin{tabular}{|c|c|c|c|c|c|c|c|c|}
\hline Cutoff type & Max & Max & Max & Max & Max & Max & Max & Max \\
\hline Cutoff level & 100 & 100 & 100 & 100 & 1000 & 1000 & 1000 & 1000 \\
\hline Dependent variable & Target & Target & Attack & Attack & Target & Target & Attack & Attack \\
\hline Islamic ideology & $\begin{array}{c}1.593 * * * \\
(0.588)\end{array}$ & $\begin{array}{c}1.520 * * * \\
(0.542)\end{array}$ & $\begin{array}{c}0.983 * * * \\
(0.378) \\
\end{array}$ & $\begin{array}{c}1.000 * * * \\
(0.388)\end{array}$ & $\begin{array}{c}1.732 * * * \\
(0.576)\end{array}$ & $\begin{array}{c}1.634 * * * \\
(0.588)\end{array}$ & $\begin{array}{c}1.044 * * * \\
(0.386)\end{array}$ & $\begin{array}{c}0.946 * * \\
(0.412) \\
\end{array}$ \\
\hline US troops (dichotomous) & $\begin{array}{l}-0.414 \\
(0.648)\end{array}$ & $\begin{array}{c}-0.591 \\
(0.619)\end{array}$ & $\begin{array}{c}0.610 \\
(0.470)\end{array}$ & $\begin{array}{c}0.825 \\
(0.578)\end{array}$ & $\begin{array}{l}-0.576 \\
(0.888)\end{array}$ & $\begin{array}{l}-1.182 \\
(1.013)\end{array}$ & $\begin{array}{c}-0.888 \\
(0.543)\end{array}$ & $\begin{array}{l}-1.464^{*} \\
(0.807)\end{array}$ \\
\hline Democracy & $\begin{array}{c}0.464 \\
(1.052)\end{array}$ & $\begin{array}{c}0.930 \\
(1.274)\end{array}$ & $\begin{array}{c}-0.500 \\
(0.519)\end{array}$ & $\begin{array}{c}-0.928 \\
(0.969)\end{array}$ & $\begin{array}{c}0.364 \\
(0.989)\end{array}$ & $\begin{array}{c}0.887 \\
(1.152)\end{array}$ & $\begin{array}{c}-0.734 \\
(0.536)\end{array}$ & $\begin{array}{c}-0.433 \\
(0.609)\end{array}$ \\
\hline US troops/Non-democratic state & & $\begin{array}{c}1.241 \\
(1.784) \\
\end{array}$ & & $\begin{array}{c}-0.811 \\
(1.132) \\
\end{array}$ & & $\begin{array}{c}2.495 \\
(2.243) \\
\end{array}$ & & $\begin{array}{c}1.905 \\
(1.263) \\
\end{array}$ \\
\hline Log exports (UN) & $\begin{array}{c}-0.283^{*} \\
(0.170)\end{array}$ & $\begin{array}{l}-0.303^{*} \\
(0.171)\end{array}$ & $\begin{array}{c}-0.468 * * * \\
(0.174)\end{array}$ & $\begin{array}{c}-0.427 * * \\
(0.178)\end{array}$ & $\begin{array}{l}-0.247 * \\
(0.141)\end{array}$ & $\begin{array}{c}-0.194 \\
(0.166)\end{array}$ & $\begin{array}{c}-0.495 * * * \\
(0.169)\end{array}$ & $\begin{array}{c}-0.475 * * * \\
(0.157)\end{array}$ \\
\hline McDonalds (dichotomous) & $\begin{array}{c}0.264 \\
(1.059) \\
\end{array}$ & $\begin{array}{c}0.008 \\
(1.098) \\
\end{array}$ & $\begin{array}{c}2.267 * * \\
(1.120)\end{array}$ & $\begin{array}{c}2.430 * * \\
(1.217)\end{array}$ & $\begin{array}{c}0.142 \\
(1.000) \\
\end{array}$ & $\begin{array}{l}-0.359 \\
(1.037) \\
\end{array}$ & $\begin{array}{c}2.919 * * * \\
(1.113)\end{array}$ & $\begin{array}{c}2.638 * * \\
(1.088)\end{array}$ \\
\hline Organizational membership & $\begin{array}{c}-0.242 \\
(0.526)\end{array}$ & $\begin{array}{l}-0.225 \\
(0.535)\end{array}$ & $\begin{array}{c}0.153 \\
(0.253)\end{array}$ & $\begin{array}{c}0.152 \\
(0.255)\end{array}$ & $\begin{array}{c}-0.185 \\
(0.494)\end{array}$ & $\begin{array}{c}-0.135 \\
(0.497) \\
\end{array}$ & $\begin{array}{c}0.097 \\
(0.262) \\
\end{array}$ & $\begin{array}{c}0.108 \\
(0.264) \\
\end{array}$ \\
\hline Alliance connections & $\begin{array}{c}0.131 * * \\
(0.062)\end{array}$ & $\begin{array}{c}0.133 * * \\
(0.063)\end{array}$ & $\begin{array}{c}0.114 * * * \\
(0.043)\end{array}$ & $\begin{array}{c}0.116^{* * *} \\
(0.044)\end{array}$ & $\begin{array}{c}0.132 * * \\
(0.062)\end{array}$ & $\begin{array}{c}0.136 * * \\
(0.064)\end{array}$ & $\begin{array}{c}0.128 * * \\
(0.052)\end{array}$ & $\begin{array}{c}0.129 * * \\
(0.052)\end{array}$ \\
\hline State sponsorship (dichotmous) & & & $\begin{array}{l}-0.299 \\
(0.516)\end{array}$ & $\begin{array}{l}-0.337 \\
(0.512)\end{array}$ & & & $\begin{array}{l}-0.365 \\
(0.513)\end{array}$ & $\begin{array}{l}-0.331 \\
(0.491)\end{array}$ \\
\hline Three or fewer attacks & $\begin{array}{c}0.205 \\
(0.809)\end{array}$ & $\begin{array}{c}0.189 \\
(0.791)\end{array}$ & $\begin{array}{c}-1.324 * * * \\
(0.360)\end{array}$ & $\begin{array}{c}-1.332 * * * \\
(0.365)\end{array}$ & $\begin{array}{c}0.224 \\
(0.835) \\
\end{array}$ & $\begin{array}{c}0.188 \\
(0.815) \\
\end{array}$ & $\begin{array}{c}-1.409 * * * \\
(0.360)\end{array}$ & $\begin{array}{c}-1.444 * * * \\
(0.362)\end{array}$ \\
\hline Military expenditures per capita & $\begin{array}{l}-0.002 \\
(0.001) \\
\end{array}$ & $\begin{array}{l}-0.002 * \\
(0.001)\end{array}$ & $\begin{array}{c}0.000 \\
(0.001)\end{array}$ & $\begin{array}{c}0.001 \\
(0.001) \\
\end{array}$ & $\begin{array}{l}-0.002 \\
(0.001) \\
\end{array}$ & $\begin{array}{c}-0.002 * * \\
(0.001)\end{array}$ & $\begin{array}{l}-0.000 \\
(0.001) \\
\end{array}$ & $\begin{array}{l}-0.001 \\
(0.001) \\
\end{array}$ \\
\hline GDP per capita & $\begin{array}{l}0.00013^{*} \\
(0.00007) \\
\end{array}$ & $\begin{array}{c}0.00014 * * \\
(0.00007)\end{array}$ & $\begin{array}{c}0.00001 \\
(0.00006) \\
\end{array}$ & $\begin{array}{c}-0.0000001 \\
(0.00007)\end{array}$ & & $\begin{array}{c}0.00016 * * \\
(0.00007)\end{array}$ & $\begin{array}{c}0.00007 \\
(0.00006) \\
\end{array}$ & $\begin{array}{c}0.00008 \\
(0.00005)\end{array}$ \\
\hline Years of internal/external civil war & & & $\begin{array}{l}-0.026 \\
(0.057)\end{array}$ & $\begin{array}{l}-0.040 \\
(0.066)\end{array}$ & & & $\begin{array}{l}-0.007 \\
(0.064)\end{array}$ & $\begin{array}{c}0.009 \\
(0.065)\end{array}$ \\
\hline Constant & $\begin{array}{c}1.745 \\
(3.954)\end{array}$ & $\begin{array}{c}2.057 \\
(3.941)\end{array}$ & $\begin{array}{l}7.516 * * \\
(3.411)\end{array}$ & $\begin{array}{l}6.820 * * \\
(3.454)\end{array}$ & $\begin{array}{c}0.807 \\
(3.232) \\
\end{array}$ & $\begin{array}{c}-0.481 \\
(3.863)\end{array}$ & $\begin{array}{l}7.929 * * \\
(3.322)\end{array}$ & $\begin{array}{l}7.409 * * \\
(3.195)\end{array}$ \\
\hline $\mathbf{N}$ & 350 & 350 & 350 & 350 & 350 & 350 & 350 & 350 \\
\hline Log-likelihood & -61.068 & -60.794 & -125.406 & -125.112 & -61.029 & -60.150 & -125.027 & -123.852 \\
\hline chi2 (LR test) & 13.865 & 14.413 & 56.957 & 57.545 & 13.944 & 15.702 & 57.715 & 60.066 \\
\hline Pseudo R2 (McFadden) & 0.102 & 0.106 & 0.185 & 0.187 & 0.103 & 0.115 & 0.188 & 0.195 \\
\hline AIC & 144.136 & 145.588 & 276.812 & 278.224 & 144.057 & 144.299 & 276.054 & 275.703 \\
\hline BIC & 186.573 & 191.883 & 326.965 & 332.235 & 186.494 & 190.594 & 326.207 & 329.714 \\
\hline
\end{tabular}

Note: Years of internal/external civil war excluded from targeting results because it predicts failure perfectly.

Table A.22: Selected Specifications of Troop Presence Variable When Excluding Iraqi and Afghani Orgs. (continued)

\begin{tabular}{|l|l|l|l|l|l|l|l|l|l|} 
Cutoff type & Max & Max & Max & Max & Max & Max & Max & Max \\
\hline
\end{tabular}




\begin{tabular}{|c|c|c|c|c|c|c|c|c|}
\hline Cutoff level & 2000 & 2000 & 2000 & 2000 & 5000 & 5000 & 5000 & 5000 \\
\hline Dependent variable & Target & Target & Attack & Attack & Target & Target & Attack & Attack \\
\hline Islamic ideology & $\begin{array}{c}1.689 * * * \\
(0.588)\end{array}$ & $\begin{array}{c}1.625 * * * \\
(0.610)\end{array}$ & $\begin{array}{c}0.966^{* * *} * \\
(0.369)\end{array}$ & $\begin{array}{c}0.957 * * \\
(0.380)\end{array}$ & $\begin{array}{c}1.655^{* * * *} \\
(0.595)\end{array}$ & $\begin{array}{c}1.588 * * * \\
(0.594)\end{array}$ & $\begin{array}{c}0.976 * * * \\
(0.365)\end{array}$ & $\begin{array}{c}0.975 * * * \\
(0.370)\end{array}$ \\
\hline US troops (dichotomous) & $\begin{array}{c}-0.281 \\
(1.084) \\
\end{array}$ & $\begin{array}{l}-1.103 \\
(1.014) \\
\end{array}$ & $\begin{array}{c}-0.854 \\
(0.743) \\
\end{array}$ & $\begin{array}{l}-1.291 \\
(0.805) \\
\end{array}$ & $\begin{array}{c}0.513 \\
(1.278) \\
\end{array}$ & $\begin{array}{c}-0.336 \\
(1.185) \\
\end{array}$ & $\begin{array}{c}-1.091 \\
(1.085) \\
\end{array}$ & $\begin{array}{l}-1.907 \\
(1.318) \\
\end{array}$ \\
\hline Democracy & $\begin{array}{c}0.463 \\
(1.006) \\
\end{array}$ & $\begin{array}{c}1.261 \\
(1.160) \\
\end{array}$ & $\begin{array}{c}-0.611 \\
(0.502)\end{array}$ & $\begin{array}{c}-0.434 \\
(0.496)\end{array}$ & $\begin{array}{c}0.531 \\
(0.944) \\
\end{array}$ & $\begin{array}{c}1.278 \\
(1.183) \\
\end{array}$ & $\begin{array}{l}-0.675 \\
(0.503)\end{array}$ & $\begin{array}{l}-0.526 \\
(0.497)\end{array}$ \\
\hline US troops/Non-democratic state & & $\begin{array}{c}6.260 * * * \\
(1.619) \\
\end{array}$ & & $\begin{array}{c}3.161 * * * \\
(1.149) \\
\end{array}$ & & $\begin{array}{c}5.495 * * * \\
(1.691) \\
\end{array}$ & & $\begin{array}{l}3.489 * * \\
(1.463)\end{array}$ \\
\hline Log exports (UN) & $\begin{array}{c}-0.258 * \\
(0.138)\end{array}$ & $\begin{array}{c}-0.300^{*} \\
(0.153)\end{array}$ & $\begin{array}{c}-0.462 * * * \\
(0.162)\end{array}$ & $\begin{array}{c}-0.491 * * * \\
(0.159)\end{array}$ & $\begin{array}{c}-0.317 * * \\
(0.143)\end{array}$ & $\begin{array}{c}-0.364 * * \\
(0.159)\end{array}$ & $\begin{array}{c}-0.446^{* * *} \\
(0.162)\end{array}$ & $\begin{array}{c}-0.464 * * * \\
(0.158)\end{array}$ \\
\hline McDonalds (dichotomous) & $\begin{array}{c}0.046 \\
(0.973) \\
\end{array}$ & $\begin{array}{l}-0.252 \\
(0.944)\end{array}$ & $\begin{array}{c}2.671 * * * \\
(1.015)\end{array}$ & $\begin{array}{c}2.665 * * \\
(1.038)\end{array}$ & $\begin{array}{c}0.114 \\
(0.978)\end{array}$ & $\begin{array}{l}-0.223 \\
(0.951)\end{array}$ & $\begin{array}{c}2.602 * * * \\
(1.006)\end{array}$ & $\begin{array}{c}2.546 * * \\
(1.015)\end{array}$ \\
\hline Organizational membership & $\begin{array}{c}-0.190 \\
(0.487)\end{array}$ & $\begin{array}{l}-0.179 \\
(0.528)\end{array}$ & $\begin{array}{c}0.086 \\
(0.261)\end{array}$ & $\begin{array}{c}0.052 \\
(0.264)\end{array}$ & $\begin{array}{l}-0.226 \\
(0.482)\end{array}$ & $\begin{array}{l}-0.186 \\
(0.513)\end{array}$ & $\begin{array}{c}0.139 \\
(0.252)\end{array}$ & $\begin{array}{c}0.134 \\
(0.253)\end{array}$ \\
\hline Alliance connections & $\begin{array}{c}0.132 * * \\
(0.061)\end{array}$ & $\begin{array}{c}0.139 * * \\
(0.068)\end{array}$ & $\begin{array}{c}0.129 * * \\
(0.052)\end{array}$ & $\begin{array}{c}0.140 * * \\
(0.056)\end{array}$ & $\begin{array}{c}0.129 * * \\
(0.060)\end{array}$ & $\begin{array}{c}0.135 * * \\
(0.064)\end{array}$ & $\begin{array}{c}0.121 * * \\
(0.048)\end{array}$ & $\begin{array}{c}0.127 * * \\
(0.050)\end{array}$ \\
\hline State sponsorship (dichotmous) & & & $\begin{array}{c}-0.337 \\
(0.508)\end{array}$ & $\begin{array}{l}-0.272 \\
(0.493)\end{array}$ & & & $\begin{array}{c}-0.381 \\
(0.522) \\
\end{array}$ & $\begin{array}{c}-0.337 \\
(0.516)\end{array}$ \\
\hline Three or fewer attacks & $\begin{array}{c}0.221 \\
(0.822) \\
\end{array}$ & $\begin{array}{c}0.125 \\
(0.862) \\
\end{array}$ & $\begin{array}{c}-1.390 * * * \\
(0.359)\end{array}$ & $\begin{array}{c}-1.431 * * * \\
(0.363)\end{array}$ & $\begin{array}{c}0.205 \\
(0.795) \\
\end{array}$ & $\begin{array}{c}0.131 \\
(0.818) \\
\end{array}$ & $\begin{array}{c}-1.363^{* * *} \\
(0.353)\end{array}$ & $\begin{array}{c}-1.390 * * * \\
(0.357)\end{array}$ \\
\hline Military expenditures per capita & $\begin{array}{c}-0.002 \\
(0.001)\end{array}$ & $\begin{array}{c}-0.003 * * \\
(0.001)\end{array}$ & $\begin{array}{l}-0.000 \\
(0.001)\end{array}$ & $\begin{array}{c}-0.001 \\
(0.001)\end{array}$ & $\begin{array}{c}-0.002 \\
(0.001)\end{array}$ & $\begin{array}{c}-0.003 * * \\
(0.001)\end{array}$ & $\begin{array}{l}-0.000 \\
(0.001)\end{array}$ & $\begin{array}{c}-0.001 \\
(0.001)\end{array}$ \\
\hline GDP per capita & $\begin{array}{l}0.00013^{*} \\
(0.00008)\end{array}$ & $\begin{array}{c}0.00018 * * \\
(0.00007)\end{array}$ & $\begin{array}{c}0.00007 \\
(0.00006)\end{array}$ & $\begin{array}{c}0.00009 \\
(0.00005)\end{array}$ & $\begin{array}{c}0.00011 \\
(0.00009)\end{array}$ & $\begin{array}{c}0.00016 * * \\
(0.00008)\end{array}$ & $\begin{array}{c}0.00006 \\
(0.00006)\end{array}$ & $\begin{array}{c}0.00008 \\
(0.00005)\end{array}$ \\
\hline Years of internal/external civil war & & & $\begin{array}{l}-0.005 \\
(0.065)\end{array}$ & $\begin{array}{c}0.021 \\
(0.062)\end{array}$ & & & $\begin{array}{l}-0.025 \\
(0.060)\end{array}$ & $\begin{array}{l}-0.008 \\
(0.056)\end{array}$ \\
\hline Constant & $\begin{array}{c}1.098 \\
(3.155)\end{array}$ & $\begin{array}{c}1.671 \\
(3.304)\end{array}$ & $\begin{array}{l}7.276 * * \\
(3.246)\end{array}$ & $\begin{array}{l}7.699 * * \\
(3.204)\end{array}$ & $\begin{array}{c}2.473 \\
(3.194)\end{array}$ & $\begin{array}{c}3.130 \\
(3.218)\end{array}$ & $\begin{array}{l}7.000 * * \\
(3.239)\end{array}$ & $\begin{array}{l}7.219 * * \\
(3.173)\end{array}$ \\
\hline $\mathbf{N}$ & 350 & 350 & 350 & 350 & 350 & 350 & 350 & 350 \\
\hline Log-likelihood & -61.239 & -57.719 & -125.603 & -124.160 & -61.159 & -58.326 & -125.681 & -124.102 \\
\hline chi2 (LR test) & 13.523 & 20.564 & 56.563 & 59.449 & 13.684 & 19.350 & 56.408 & 59.565 \\
\hline Pseudo R2 (McFadden) & 0.099 & 0.151 & 0.184 & 0.193 & 0.101 & 0.142 & 0.183 & 0.194 \\
\hline AIC & 144.478 & 137.437 & 277.206 & 274.320 & 144.317 & 138.651 & 277.361 & 274.203 \\
\hline BIC & 186.915 & 179.875 & 327.359 & 324.473 & 186.754 & 181.088 & 327.514 & 324.357 \\
\hline
\end{tabular}

Note: Years of internal/external civil war excluded from targeting results because it predicts failure perfectly.

Table A.23: $\quad$ Selected Predict Probabilities, Selected Specifications of Troop Presence Variable

When Excluding Iraqi and Afghani Organizations

\begin{tabular}{|c|c|c|c|c|c|c|c|c|}
\hline & Targeting & Targeting & Attacking & Attacking & Targeting & Targeting & Attacking & Attacking \\
\hline & No & With & No & With & No & With & No & With \\
\hline
\end{tabular}




\begin{tabular}{|c|c|c|c|c|c|c|c|c|}
\hline & Interactive & Interactive & Interactive & Interactive & Interactive & Interactive & Interactive & Interactive \\
\hline & Max 100 & Max 100 & Max 100 & Max 100 & Max 1000 & Max 1000 & Max 1000 & Max 1000 \\
\hline Probability at the means & 0.0357 & 0.0355 & 0.1142 & 0.1133 & 0.0352 & 0.0335 & 0.1146 & 0.1111 \\
\hline \multicolumn{9}{|l|}{ Islamic ideology } \\
\hline Yes & 0.1151 & 0.1087 & 0.2187 & 0.2195 & 0.1252 & 0.1116 & 0.2277 & 0.0928 \\
\hline No & 0.0258 & 0.0260 & 0.0948 & 0.0937 & 0.0247 & 0.0239 & 0.0940 & 0.2085 \\
\hline \multicolumn{9}{|l|}{ US troops (dichotomous) } \\
\hline Yes & NS & NS & NS & NS & NS & NS & NS & 0.0366 \\
\hline No & NS & NS & NS & NS & NS & NS & NS & 0.1409 \\
\hline \multicolumn{9}{|l|}{ US troops/Non-democratic state } \\
\hline Yes & N/A & NS & N/A & NS & N/A & NS & N/A & NS \\
\hline No & N/A & NS & N/A & NS & N/A & NS & N/A & NS \\
\hline \multicolumn{9}{|l|}{ Log exports (UN) } \\
\hline+1 std. deviation & 0.0216 & 0.0207 & 0.0519 & 0.0552 & 0.0227 & 0.0237 & 0.0497 & 0.0498 \\
\hline-1 std. deviation & 0.0589 & 0.0606 & 0.2350 & 0.2201 & 0.0545 & 0.0472 & 0.2446 & 0.2315 \\
\hline \multicolumn{9}{|l|}{ McDonalds (dichotomous) } \\
\hline Yes & NS & NS & 0.1432 & 0.1443 & NS & NS & 0.1530 & 0.1445 \\
\hline No & NS & NS & 0.0170 & 0.0146 & NS & NS & 0.0097 & 0.0119 \\
\hline \multicolumn{9}{|l|}{ Alliance connections } \\
\hline No connections & 0.0300 & 0.0297 & 0.0993 & 0.0982 & 0.0295 & 0.0279 & 0.0978 & 0.0947 \\
\hline+1 std. deviation & 0.0492 & 0.0491 & 0.1470 & 0.1464 & 0.0487 & 0.0467 & 0.1519 & 0.1479 \\
\hline+2 std. deviation & 0.0673 & 0.0674 & 0.1871 & 0.1872 & 0.0668 & 0.0648 & 0.1986 & 0.1942 \\
\hline \multicolumn{9}{|l|}{ Three or fewer attacks } \\
\hline Yes & NS & NS & 0.0838 & 0.0829 & NS & NS & 0.0823 & 0.0791 \\
\hline No & NS & NS & 0.2558 & 0.2550 & NS & NS & 0.2684 & 0.2668 \\
\hline \multicolumn{9}{|l|}{ Years of internal/external civil war } \\
\hline No years & N/A & N/A & NS & NS & N/A & N/A & NS & NS \\
\hline+1 std. deviation & N/A & N/A & NS & NS & N/A & N/A & NS & NS \\
\hline
\end{tabular}

Note: Years of internal/external civil war excluded from targeting results because it predicts failure perfectly. 
Table A.24: Selected Predict Probabilities, Selected Specifications of Troop Presence Variable When Excluding Iraqi and Afghani Organizations (continued)

\begin{tabular}{|c|c|c|c|c|c|c|c|c|}
\hline & Targeting & Targeting & Attacking & Attacking & Targeting & Targeting & Attacking & Attacking \\
\hline & No & With & No & With & No & With & No & With \\
\hline & Interactive & Interactive & Interactive & Interactive & Interactive & Interactive & Interactive & Interactive \\
\hline & Max 2000 & Max 2000 & Max 2000 & Max 2000 & Max 5000 & Max 5000 & Max 5000 & Max 5000 \\
\hline Probability at the means & 0.0356 & 0.0294 & 0.1159 & 0.1118 & 0.0353 & 0.0300 & 0.1152 & 0.1089 \\
\hline \multicolumn{9}{|l|}{ Islamic ideology } \\
\hline Yes & 0.1226 & 0.0983 & 0.2192 & 0.2112 & 0.1188 & 0.0988 & 0.2193 & 0.2086 \\
\hline $\mathrm{No}$ & 0.0252 & 0.0210 & 0.0966 & 0.0930 & 0.0251 & 0.0219 & 0.0957 & 0.0904 \\
\hline \multicolumn{9}{|l|}{ US troops (dichotomous) } \\
\hline Yes & NS & NS & NS & NS & NS & NS & NS & NS \\
\hline No & NS & NS & NS & NS & NS & NS & NS & NS \\
\hline \multicolumn{9}{|l|}{ US troops/Non-democratic state } \\
\hline Yes & N/A & 0.9385 & N/A & 0.7446 & N/A & 0.8808 & N/A & 0.7969 \\
\hline No & N/A & 0.0284 & N/A & 0.1100 & N/A & 0.0295 & N/A & 0.1070 \\
\hline \multicolumn{9}{|l|}{ Log exports (UN) } \\
\hline+1 std. deviation & 0.0225 & 0.0172 & 0.0533 & 0.0488 & 0.0201 & 0.0159 & 0.0544 & 0.0497 \\
\hline-1 std. deviation & 0.0562 & 0.0501 & 0.2358 & 0.2381 & 0.0617 & 0.0579 & 0.2293 & 0.2241 \\
\hline \multicolumn{9}{|l|}{ McDonalds (dichotomous) } \\
\hline Yes & NS & NS & 0.1510 & 0.1458 & NS & NS & 0.1491 & 0.1405 \\
\hline No & NS & NS & 0.0122 & 0.0117 & NS & NS & 0.0128 & 0.0126 \\
\hline \multicolumn{9}{|l|}{ Alliance connections } \\
\hline No connections & 0.0298 & 0.0243 & 0.0989 & 0.0940 & 0.0297 & 0.0253 & 0.0992 & 0.0930 \\
\hline+1 std. deviation & 0.0491 & 0.0414 & 0.1540 & 0.1523 & 0.0483 & 0.0424 & 0.1504 & 0.1443 \\
\hline+2 std. deviation & 0.0674 & 0.0580 & 0.2017 & 0.2041 & 0.0659 & 0.0588 & 0.1939 & 0.1888 \\
\hline \multicolumn{9}{|l|}{ Three or fewer attacks } \\
\hline Yes & NS & NS & 0.0837 & 0.0798 & NS & NS & 0.0837 & 0.0784 \\
\hline No & NS & NS & 0.2684 & 0.2662 & NS & NS & 0.2630 & 0.2548 \\
\hline \multicolumn{9}{|l|}{ Years of internal/external civil war } \\
\hline No years & N/A & N/A & NS & NS & N/A & N/A & NS & NS \\
\hline+1 std. deviation & N/A & N/A & NS & NS & N/A & N/A & NS & NS \\
\hline
\end{tabular}

Note: Years of internal/external civil war excluded from targeting results because it predicts failure perfectly. 
Table A.25: Correlations Between Dependent and Independent Variables - US Troop Presence Specified as Max 2000

\begin{tabular}{|c|c|c|c|c|c|c|c|c|c|c|c|c|c|c|c|c|}
\hline & & 1 & 2 & 3 & 4 & 5 & 6 & 7 & 8 & 9 & 10 & 11 & 12 & 13 & 14 & 15 \\
\hline 1 & Attacking the US & 1 & & & & & & & & & & & & & & \\
\hline 2 & Targeting the US & 0.364 & 1 & & & & & & & & & & & & & \\
\hline 3 & Islamic ideology & 0.162 & 0.348 & 1 & & & & & & & & & & & & \\
\hline 4 & $\begin{array}{r}\text { US troops } \\
\text { (dichotomous) }\end{array}$ & -0.033 & 0.356 & 0.172 & 1 & & & & & & & & & & & \\
\hline 5 & Democracy & -0.07 & -0.312 & -0.473 & -0.172 & 1 & & & & & & & & & & \\
\hline 6 & $\begin{array}{l}\text { US troops/Non- } \\
\text { democratic state }\end{array}$ & 0.099 & 0.619 & 0.481 & 0.591 & -0.538 & 1 & & & & & & & & & \\
\hline 7 & Log exports (UN) & -0.116 & -0.121 & -0.126 & 0.287 & 0.373 & -0.132 & 1 & & & & & & & & \\
\hline 8 & $\begin{array}{r}\text { McDonalds } \\
\text { (dichotomous) }\end{array}$ & 0.002 & -0.401 & -0.397 & -0.276 & 0.715 & -0.629 & 0.442 & 1 & & & & & & & \\
\hline 9 & $\begin{array}{r}\text { Organizational } \\
\text { membership }\end{array}$ & 0.118 & -0.012 & 0.08 & -0.109 & -0.187 & -0.034 & -0.152 & -0.13 & 1 & & & & & & \\
\hline 10 & Alliance connections & 0.263 & 0.159 & 0.182 & 0.074 & 0.089 & 0.027 & 0.047 & 0.057 & 0.288 & 1 & & & & & \\
\hline 11 & $\begin{array}{r}\text { State sponsorship } \\
\text { (dichotmous) }\end{array}$ & 0.088 & -0.046 & 0.127 & -0.083 & -0.106 & -0.038 & -0.173 & -0.015 & 0.365 & 0.205 & 1 & & & & \\
\hline 12 & $\begin{array}{r}\text { Three or fewer } \\
\text { attacks } \\
\end{array}$ & -0.27 & -0.019 & -0.045 & -0.027 & 0.005 & 0.039 & 0.007 & 0.034 & -0.373 & -0.38 & -0.19 & 1 & & & \\
\hline 13 & $\begin{array}{r}\text { Military } \\
\text { expenditures per } \\
\text { capita } \\
\end{array}$ & 0.025 & -0.142 & -0.163 & -0.097 & 0.317 & -0.174 & 0.241 & 0.32 & -0.177 & 0.052 & 0.019 & -0.001 & 1 & & \\
\hline 14 & GDP per capita & -0.067 & -0.191 & -0.407 & 0.144 & 0.519 & -0.306 & 0.515 & 0.469 & -0.344 & -0.039 & -0.137 & 0.056 & 0.723 & 1 & \\
\hline 15 & $\begin{array}{r}\text { Years of } \\
\text { internal/external } \\
\text { civil war }\end{array}$ & -0.006 & -0.1 & 0.098 & -0.086 & -0.177 & -0.01 & -0.051 & -0.08 & 0.39 & 0.107 & 0.244 & -0.206 & 0.046 & -0.329 & 1 \\
\hline
\end{tabular}

Note: Shaded cells indicate correlation greater than 0.60 cutoff for possible collinearity. 
Table A.26: Variance Inflation Factor (VIF) Tests for OLS Models of Target and Attacking Behavior - Selected Specifications

\begin{tabular}{|c|c|c|c|c|c|c|c|c|}
\hline Cutoff type & Max & Max & Max & Max & Max & Max & Max & Max \\
\hline Cutoff level & 100 & 100 & 100 & 100 & 1000 & 1000 & 1000 & 1000 \\
\hline Dependent variable & Target & Target & Attack & Attack & Target & Target & Attack & Attack \\
\hline Islamic ideology & 1.70 & 1.75 & 1.70 & 1.75 & 1.75 & 1.80 & 1.75 & 1.80 \\
\hline US troops (dichotomous) & 1.23 & 2.04 & 1.23 & 2.04 & 1.52 & 2.67 & 1.52 & 2.67 \\
\hline Democracy & 2.52 & 3.61 & 2.52 & 3.61 & 2.53 & 2.65 & 2.53 & 2.65 \\
\hline US troops/Non-democratic state & & 3.62 & & 3.62 & & 3.52 & & 3.52 \\
\hline Log exports (UN) & 1.89 & 2.19 & 1.89 & 2.19 & 1.93 & 1.93 & 1.93 & 1.93 \\
\hline McDonalds (dichotomous) & 2.34 & 2.37 & 2.34 & 2.37 & 2.46 & 2.55 & 2.46 & 2.55 \\
\hline Organizational membership & 1.64 & 1.65 & 1.64 & 1.65 & 1.61 & 1.63 & 1.61 & 1.63 \\
\hline Alliance connections & 1.34 & 1.35 & 1.34 & 1.35 & 1.36 & 1.36 & 1.36 & 1.36 \\
\hline State sponsorship (dichotmous) & 1.27 & 1.27 & 1.27 & 1.27 & 1.26 & 1.26 & 1.26 & 1.26 \\
\hline Three or fewer attacks & 1.31 & 1.31 & 1.31 & 1.31 & 1.31 & 1.32 & 1.31 & 1.32 \\
\hline Military expenditures per capita & 3.48 & 4.07 & 3.48 & 4.07 & 3.64 & 4.24 & 3.64 & 4.24 \\
\hline GDP per capita & 6.05 & 7.20 & 6.05 & 7.20 & 6.33 & 7.50 & 6.33 & 7.50 \\
\hline Years of internal/external civil war & 1.75 & 1.80 & 1.75 & 1.80 & 1.76 & 1.90 & 1.76 & 1.90 \\
\hline Mean VIF & 2.21 & 2.63 & 2.21 & 2.63 & 2.29 & 2.64 & 2.29 & 2.64 \\
\hline Max VIF & 6.05 & 7.20 & 6.05 & 7.20 & 6.33 & 7.50 & 6.33 & 7.50 \\
\hline
\end{tabular}


Table A.27: Variance Inflation Factor (VIF) Tests for OLS Models of Target and Attacking Behavior - Selected Specifications (continued)

\begin{tabular}{|c|c|c|c|c|c|c|c|c|}
\hline Cutoff type & Max & Max & Max & Max & Max & Max & Max & Max \\
\hline Cutoff level & 2000 & 2000 & 2000 & 2000 & 5000 & 5000 & 5000 & 5000 \\
\hline Dependent variable & Target & Target & Attack & Attack & Target & Target & Attack & Attack \\
\hline Islamic ideology & 1.73 & 1.76 & 1.73 & 1.76 & 1.75 & 1.76 & 1.75 & 1.76 \\
\hline US troops (dichotomous) & 1.69 & 2.86 & 1.69 & 2.86 & 1.9 & 3.72 & 1.9 & 3.72 \\
\hline Democracy & 2.5 & 2.53 & 2.5 & 2.53 & 2.54 & 2.54 & 2.54 & 2.54 \\
\hline US troops/Non-democratic state & & 3.49 & & 3.49 & & 4.03 & & 4.03 \\
\hline Log exports (UN) & 2.01 & 2.02 & 2.01 & 2.02 & 2.07 & 2.07 & 2.07 & 2.07 \\
\hline McDonalds (dichotomous) & 2.67 & 2.92 & 2.67 & 2.92 & 2.8 & 2.95 & 2.8 & 2.95 \\
\hline Organizational membership & 1.62 & 1.63 & 1.62 & 1.63 & 1.6 & 1.65 & 1.6 & 1.65 \\
\hline Alliance connections & 1.37 & 1.37 & 1.37 & 1.37 & 1.36 & 1.36 & 1.36 & 1.36 \\
\hline State sponsorship (dichotmous) & 1.26 & 1.26 & 1.26 & 1.26 & 1.26 & 1.26 & 1.26 & 1.26 \\
\hline Three or fewer attacks & 1.31 & 1.32 & 1.31 & 1.32 & 1.31 & 1.31 & 1.31 & 1.31 \\
\hline Military expenditures per capita & 3.66 & 4.34 & 3.66 & 4.34 & 3.48 & 4.11 & 3.48 & 4.11 \\
\hline GDP per capita & 6.42 & 7.74 & 6.42 & 7.74 & 6.35 & 7.98 & 6.35 & 7.98 \\
\hline Years of internal/external civil war & 1.78 & 1.91 & 1.78 & 1.91 & 1.75 & 1.78 & 1.75 & 1.78 \\
\hline Mean VIF & 2.33 & 2.7 & 2.33 & 2.7 & 2.35 & 2.81 & 2.35 & 2.81 \\
\hline Max VIF & 6.42 & 7.74 & 6.42 & 7.74 & 6.35 & 7.98 & 6.35 & 7.98 \\
\hline
\end{tabular}


Table A.28: Comparison of Model Coefficients With and Without Organizational Membership Variable

\begin{tabular}{|c|c|c|c|c|c|c|c|c|c|c|c|c|}
\hline \multirow[b]{2}{*}{ Cutoff type } & \multicolumn{4}{|c|}{ Model With Organizational Membership } & \multicolumn{4}{|c|}{ Model Without Organizational Membership } & \multirow{4}{*}{\multicolumn{4}{|c|}{$\begin{array}{c}\text { Percentage Difference Between } \\
\text { Coefficients, Models With and } \\
\text { Without Organizational } \\
\text { Membership }\end{array}$}} \\
\hline & Max & Max & Max & Max & Max & Max & Max & Max & & & & \\
\hline Cutoff level & 2000 & 2000 & 2000 & 2000 & 2000 & 2000 & 2000 & 2000 & & & & \\
\hline Dependent variable & Target & Target & Attack & Attack & Target & Target & Attack & Attack & & & & \\
\hline \multirow[t]{2}{*}{ Islamic ideology } & $0.944 *$ & $1.121 *$ & $0.683 *$ & 0.586 & $0.940 *$ & $1.148 *$ & $0.689 * *$ & 0.588 & $0 \%$ & $-2 \%$ & $-1 \%$ & $0 \%$ \\
\hline & $(0.538)$ & $(0.624)$ & $(0.376)$ & $(0.427)$ & $(0.541)$ & $(0.628)$ & $(0.343)$ & $(0.394)$ & & & & \\
\hline \multirow[t]{2}{*}{ Max 2000 US troops (dichotomous) } & $2.504 * * *$ & -0.958 & 0.019 & -1.471 & $2.517 * * *$ & -0.905 & 0.022 & -1.471 & $-1 \%$ & $6 \%$ & $-16 \%$ & $0 \%$ \\
\hline & $(0.627)$ & $(1.082)$ & $(0.451)$ & $(0.921)$ & $(0.632)$ & $(1.133)$ & $(0.458)$ & $(0.927)$ & & & & \\
\hline \multirow[t]{2}{*}{ Democracy } & -0.068 & 0.608 & -0.777 & -0.641 & -0.069 & 0.606 & -0.774 & -0.640 & $-1 \%$ & $0 \%$ & $0 \%$ & $0 \%$ \\
\hline & $(0.664)$ & $(1.067)$ & $(0.477)$ & $(0.478)$ & $(0.666)$ & $(1.053)$ & $(0.477)$ & $(0.478)$ & & & & \\
\hline \multirow[t]{2}{*}{ US troops/Non-democratic state } & & $5.989 * * *$ & & $3.048 * *$ & & $5.880 * * *$ & & $3.048 * *$ & & $-1 \%$ & & $0 \%$ \\
\hline & & $(1.530)$ & & $(1.221)$ & & $(1.546)$ & & $(1.219)$ & & & & \\
\hline \multirow[t]{2}{*}{ Log exports (UN) } & $-0.308 * *$ & $-0.423 * * *$ & $-0.244 * *$ & $-0.270 * *$ & $-0.309 * *$ & $-0.42 * * *$ & $-0.244 * *$ & $-0.270^{* *}$ & $0 \%$ & $0 \%$ & $0 \%$ & $0 \%$ \\
\hline & $(0.133)$ & $(0.112)$ & $(0.121)$ & $(0.130)$ & $(0.133)$ & $(0.113)$ & $(0.121)$ & $(0.129)$ & & & & \\
\hline \multirow[t]{2}{*}{ McDonalds (dichotomous) } & -0.967 & -0.058 & $1.274 * *$ & $2.057 * * *$ & -0.968 & -0.035 & $1.274 * *$ & $2.056^{* * *}$ & $0 \%$ & $40 \%$ & $0 \%$ & $0 \%$ \\
\hline & $(0.632)$ & $(0.766)$ & $(0.606)$ & $(0.695)$ & $(0.632)$ & $(0.780)$ & $(0.608)$ & $(0.702)$ & & & & \\
\hline \multirow[t]{2}{*}{ Organizational membership } & -0.090 & 0.182 & -0.020 & -0.006 & & & & & & & & \\
\hline & $(0.345)$ & $(0.423)$ & $(0.228)$ & $(0.241)$ & & & & & & & & \\
\hline \multirow[t]{2}{*}{ Alliance connections } & $0.145^{* *}$ & $0.132 *$ & $0.186^{* *}$ & $0.190 * *$ & $0.144 * *$ & $0.134 *$ & $0.184 * *$ & $0.190 * *$ & $1 \%$ & $-2 \%$ & $1 \%$ & $0 \%$ \\
\hline & $(0.068)$ & $(0.077)$ & $(0.075)$ & $(0.080)$ & $(0.069)$ & $(0.077)$ & $(0.072)$ & $(0.077)$ & & & & \\
\hline \multirow[t]{2}{*}{ State sponsorship (dichotmous) } & $-0.943 *$ & -0.900 & -0.344 & -0.235 & $-1.010^{*}$ & -0.744 & -0.356 & -0.238 & $-7 \%$ & $17 \%$ & $-3 \%$ & $-1 \%$ \\
\hline & $(0.547)$ & $(0.600)$ & $(0.505)$ & $(0.524)$ & $(0.573)$ & $(0.635)$ & $(0.553)$ & $(0.577)$ & & & & \\
\hline \multirow[t]{2}{*}{ Three or fewer attacks } & -0.229 & -0.387 & $-1.318 * * *$ & $-1.458 * * *$ & -0.186 & -0.458 & $\begin{array}{c}- \\
1.311^{* * * *}\end{array}$ & $\begin{array}{c}- \\
1.455^{* * *}\end{array}$ & $19 \%$ & $-18 \%$ & $1 \%$ & $0 \%$ \\
\hline & $(0.542)$ & $(0.658)$ & $(0.322)$ & $(0.336)$ & $(0.457)$ & $(0.557)$ & $(0.328)$ & $(0.329)$ & & & & \\
\hline \multirow[t]{2}{*}{ Military expenditures per capita } & 0.001 & $-0.004 * *$ & 0.001 & -0.000 & 0.001 & $-0.004 * *$ & 0.001 & -0.000 & $0 \%$ & $0 \%$ & $0 \%$ & $0 \%$ \\
\hline & $(0.002)$ & $(0.002)$ & $(0.001)$ & $(0.001)$ & $(0.002)$ & $(0.002)$ & $(0.001)$ & $(0.001)$ & & & & \\
\hline \multirow[t]{2}{*}{ GDP per capita } & -0.00005 & $0.00019 * *$ & -0.00002 & 0.00004 & -0.000 & $0.000 * * *$ & -0.000 & 0.000 & $0 \%$ & $0 \%$ & $0 \%$ & $0 \%$ \\
\hline & $(0.00009)$ & $(0.00007)$ & $(0.00006)$ & $(0.00005)$ & $(0.000)$ & $(0.000)$ & $(0.000)$ & $(0.000)$ & & & & \\
\hline \multirow[t]{2}{*}{ Years of internal/external civil war } & $-0.347 * * *$ & $-0.463 * * *$ & -0.092 & -0.050 & $-0.35 * * *$ & $-0.46 * * *$ & -0.093 & -0.050 & $-1 \%$ & $1 \%$ & $-1 \%$ & $0 \%$ \\
\hline & $(0.087)$ & $(0.114)$ & $(0.064)$ & $(0.067)$ & $(0.087)$ & $(0.113)$ & $(0.067)$ & $(0.068)$ & & & & \\
\hline \multirow[t]{2}{*}{ Constant } & $5.288^{*}$ & $5.795 * *$ & $4.313^{*}$ & 3.833 & $5.213^{*}$ & $5.900 * *$ & $4.305^{*}$ & 3.829 & $1 \%$ & $-2 \%$ & $0 \%$ & $0 \%$ \\
\hline & $(3.120)$ & $(2.587)$ & $(2.587)$ & $(2.802)$ & $(2.985)$ & $(2.508)$ & $(2.600)$ & $(2.793)$ & & & & \\
\hline $\mathbf{N}$ & 387 & 387 & 387 & 387 & 387 & 387 & 387 & 387 & & & & \\
\hline Log-likelihood & -83.355 & -74.894 & -148.865 & -144.178 & -83.39 & -74.995 & -148.869 & -144.179 & & & & \\
\hline chi2 (Wald) & 232.445 & 604.187 & 56.518 & 70.394 & 223.265 & 614.197 & 50.942 & 65.674 & & & & \\
\hline Pseudo R2 (McFadden) & 0.383 & 0.445 & 0.158 & 0.184 & 0.382 & 0.444 & 0.158 & 0.184 & & & & \\
\hline AIC & 192.711 & 177.788 & 323.730 & 316.357 & 190.781 & 175.991 & 321.737 & 314.357 & & & & \\
\hline BIC & 244.170 & 233.206 & 375.189 & 371.775 & 238.282 & 227.45 & 369.238 & 365.817 & & & & \\
\hline
\end{tabular}

